\title{
Total and heterotrophic soil respiration in a swamp forest and oil palm plantations on peat in Central Kalimantan, Indonesia
}

\author{
Kristell Hergoualc'h • Dede T. Hendry - Daniel Murdiyarso - Louis Vincent Verchot
}

Received: 24 May 2017/ Accepted: 18 July 2017 / Published online: 7 September 2017

(C) The Author(s) 2017. This article is an open access publication

\begin{abstract}
Heterotrophic respiration is a major component of the soil $\mathrm{C}$ balance however we critically lack understanding of its variation upon conversion of peat swamp forests in tropical areas. Our research focused on a primary peat swamp forest and two oil palm plantations aged 1 (OP2012) and 6 years (OP2007). Total and heterotrophic soil respiration were monitored over 13 months in paired control and trenched plots. Spatial variability was taken into account by differentiating hummocks from hollows in the forest; close to palm from far from palm positions in the plantations. Annual total soil respiration was the
\end{abstract}

Responsible Editor: Melany Fisk.

K. Hergoualc'h · D. T. Hendry · D. Murdiyarso ·

L. V. Verchot

Center for International Forestry Research (CIFOR), Jl.

CIFOR, Situ Gede, Bogor 16115, Indonesia

D. T. Hendry

Department of Science at Natural Resources and

Environmental Management, Bogor Agricultural Institute

(IPB), Bogor, Indonesia

L. V. Verchot

Center for International Tropical Agriculture (CIAT), Km

17, Recta Cali-Palmira, Cali, Colombia

K. Hergoualc'h $(\bowtie)$

Center for International Forestry Research, CIFOR c/o

Centro Internacional de la Papa (CIP), Av. La Molina

1895, La Molina, Apdo postal 1558, 15024 Lima, Peru

e-mail: k.hergoualch@cgiar.org highest in the oldest plantation $(13.8 \pm 0.3 \mathrm{Mg} \mathrm{C}$ $\mathrm{ha}^{-1}$ year $^{-1}$ ) followed by the forest and youngest plantation $\left(12.9 \pm 0.3\right.$ and $11.7 \pm 0.4 \mathrm{Mg} \mathrm{C} \mathrm{ha}{ }^{-1}$ year $^{-1}$, respectively). In contrast, the contribution of heterotrophic to total respiration and annual heterotrophic respiration were lower in the forest $\left(55.1 \pm 2.8 \% ; 7.1 \pm 0.4 \mathrm{Mg} \mathrm{C} \mathrm{ha}^{-1}\right.$ year $\left.^{-1}\right)$ than in the plantations $(82.5 \pm 5.8$ and $61.0 \pm 2.3 \%$; $9.6 \pm 0.8$ and $8.4 \pm 0.3 \mathrm{Mg} \mathrm{C} \mathrm{ha}{ }^{-1}$ year $^{-1}$ in the OP2012 and OP2007, respectively). The use of total soil respiration rates measured far from palms as an indicator of heterotrophic respiration, as proposed in the literature, overestimates peat and litter mineralization by around $21 \%$. Preliminary budget estimates suggest that over the monitoring period, the peat was a net $\mathrm{C}$ source in all land uses; $\mathrm{C}$ loss in the plantations was more than twice the loss observed in the forest.

Keywords $\mathrm{CO}_{2}$ emissions $\cdot$ Greenhouse gas $\cdot$ Landuse change - Soil respiration partitioning - Trenching · Tropics

\section{Introduction}

Indonesia is one of the main holders of peatlands in the tropics with an estimated area of $225,000 \mathrm{~km}^{2}$ (Gumbricht et al. 2017), of which about $14-18 \%$ is located in Central Kalimantan (Warren et al. 2017). Apart from being the habitat of rare species and providing 
hydrological regulation services, Indonesian peat swamp forests play a prominent role as a global carbon (C) pool and sink. In their pristine status, they are estimated to store on average $220 \mathrm{Mg} \mathrm{Cha}^{-1}$ in the phytomass (Hergoualc'h and Verchot 2011) and as much as $670 \mathrm{Mg} \mathrm{C} \mathrm{ha}^{-1} \mathrm{~m}^{-1}$ depth of peat (Warren et al. 2012). Peat $C$ stores have accumulated over millennia as the result of a simultaneous high primary productivity, and low decomposition rates in waterlogged conditions. While in some regions of Indonesia peat swamp forests are still accumulating peat, in others such as in Central Kalimantan, peat growth may have ceased following intensification of El Niño activity during the late Holocene (Dommain et al. 2011) although knowledge on current accumulation or loss rates is lacking.

Indonesian peat swamp forests have experienced continued deforestation and conversion over the past decades (Miettinen et al. 2016).The proportion of pristine and degraded peat swamp forest in Sumatra and Kalimantan fell from 76\% in 1990, to $40 \%$ in 2007 and $29 \%$ in 2015. Kalimantan though has retained a higher proportion of peat forest $(42 \%)$ than Sumatra (18\%). Unsustainable logging activities, uncontrolled fires and unsupervised agricultural development have sequentially led to dramatic declines of the extent of peat swamp forests in these regions. Between 2007 and 2015, most converted forests $(73 \%)$ were turned into smallholder fields and industrial plantations. Forest to industrial plantations was the main conversion type in Kalimantan (64\% versus $4 \%$ for conversion to smallholder fields) whereas in Sumatra conversion by smallholders was substantial $(30 \%$ versus $44 \%$ for conversion to industrial plantations). In Kalimantan newly established industrial plantations were mostly oil palm plantations (90\%) (Miettinen et al. 2016). There is no information on land cover type to which smallholders converted forests, but oil palm plantations are also likely to represent the most dominant land use.

Peat forest conversion to oil palm plantation implies drastic vegetation cover changes and drainage of the land, which turns the potential $\mathrm{C}$ sink into a major source (Hergoualc'h and Verchot 2014). The conversion is estimated to release as much as $2216 \mathrm{Mg}$ $\mathrm{CO}_{2}$ eq ha ${ }^{-1}$ over 25 years (Drösler et al. 2014; Hergoualc'h et al. 2017; Hergoualc'h and Verchot $2011)$; $50 \%$ of which are from peat decomposition; $26 \%$ from biomass changes and the rest corresponding to one fire. Fires used for land-clearing can spread out of control and release massive emissions of greenhouse gases to the atmosphere; which is the cause of major international concern (Gaveau et al. 2014). Quantification of peat C losses from forest conversion requires knowledge of the main elements contributing to increase or decrease the pool size. Carbon enters the peat in the form of above and belowground litter, it leaves through peat and litter mineralization (or heterotrophic soil respiration-SRh), fires, methane emissions, and dissolved and particulate organic C (Hergoualc'h and Verchot 2014). SRh is a major source of $\mathrm{C}$ loss and a key component of the soil C balance in tropical peatlands (Hergoualc' $h$ and Verchot 2014) however current assessments in forests and oil palm plantations on peat are based on a very limited number of studies (Dariah et al. 2014; Ishida et al. 2001; Melling et al. 2007). In addition, several studies evaluating peat $\mathrm{C}$ loss such as the study by Hooijer et al. (2010) have not dissociated total from heterotrophic soil respiration or total soil respiration from net $\mathrm{CO}_{2}$ emissions. Soil respiration is made up of autotrophic respiration (by roots) and heterotrophic respiration (by microbes and soil fauna) however only the second component of the respiration contributes to peat $\mathrm{C}$ loss to the atmosphere (Bond-Lamberty and Thompson 2010; Hergoualc'h and Verchot 2011; Ryan and Law 2005). Although root respiration integrates heterotrophic activity in the rhizosphere, we don't consider this distinction in the current study.

Partitioning total soil respiration (SRt) into its autotrophic and heterotrophic components is difficult. For this, various methods have been developed and used under both laboratory and field conditions. These encompass root trenching, root biomass regression, tree girdling, measuring respiration of excised or living roots and incubation of root-free soil. Isotopic methods include continuous or pulse labeling of shoots in ${ }^{14} \mathrm{CO}_{2}$, air $\mathrm{CO}_{2}$ enrichment, radiocarbon dating of soil $\mathrm{CO}_{2}$, bomb- ${ }^{14} \mathrm{CO}_{2}$, and ${ }^{18} \mathrm{O}$ of $\mathrm{CO}_{2}$ (Kuzyakov 2006). All methods present biases and uncertainties. Isotopic methods allow non-destructive partitioning but are expensive and not always applicable (Ryan and Law 2005). Among the non-isotopic methods available, regression between root biomass and SRt in oil palm plantations on peat has proved to be weak (Dariah et al. 2014). Tree girdling often induces tree death (Kuzyakov 2006) and is thus problematic to implement in commercial oil palm plantations. 
Extrapolating respiration rates of excised or living roots to field scales is complicated and usually considered as inexact (Kuzyakov 2006). The advantage of incubating soil mesocosms over trenching is the near absence of dead roots that can potentially contribute to increase SRh rates in trenching experiments (Hanson et al. 2000). Its disadvantage is the high disturbance of soil physical structure when removing roots and re-packing. Here we opted for the root trenching method to partition soil respiration in situ and characterize temporal variations of SRt and SRh.

We studied a primary peat swamp forest and two oil palm plantations on peat with different ages ( 1 year old-OP2012 and 6 year old-OP2007) in Central Kalimantan, Indonesia. We combined the trenching method with the dynamic closed chamber technique to measure total and heterotrophic soil respiration over 13 months (from June 2013 to June 2014). To account for variation along microtopographic and microclimatic gradients, we employed a spatially-stratified experimental design distinguishing hollows from hummocks in the forest, and close to palm from far from palm positions in the plantations. The distinction in the plantations also accounts for soil management differences between these areas as typically only areas near palms receive fertilizer applications. Concomitantly with soil respiration measurements, we monitored the key environmental variables known to influence flux variations. Our main objective was to quantify how soil $\mathrm{C}$ losses through SRh differed between a swamp forest and oil palm plantations on peat. The second objective was to evaluate the contribution of SRh to SRt for further use in studies monitoring SRt exclusively. Our third objective was to examine the control that environmental factors, including climatic and edaphic variables, can exert on SRt and SRh rates over time and across land uses.

\section{Materials and methods}

Study sites

The research was conducted in and around the national park of Tanjung Puting in the province of Central Kalimantan, Indonesia. The park is about 400,000 ha and is famous for its conservation and rehabilitation center for orangutans (Pongo pygmaeus, a peat swamp forest endemic species), gibbons (Hylobates spp), red Langur (Presbytis rubicunda) and proboscis monkey (Nasalis larvatus). Long-term average annual temperature and rainfall in the area during 2004-2014 are $27{ }^{\circ} \mathrm{C}$ and $2058 \mathrm{~mm}$, with no clear seasonal pattern (Swails et al. 2017).

The study included a forest site $\left(2^{\circ} 49^{\prime} 21^{\prime \prime} \mathrm{S}\right.$, $\left.111^{\circ} 50^{\prime} 24^{\prime \prime} \mathrm{E}\right)$ situated inside the national park and two oil palm plantations (OP2012, $2^{\circ} 47^{\prime} 39^{\prime \prime} \mathrm{S}$, $111^{\circ} 48^{\prime} 64^{\prime \prime} \mathrm{E} ; \quad \mathrm{OP} 2007, \quad 2^{\circ} 47^{\prime} 28^{\prime \prime} \mathrm{S}, \quad 111^{\circ} 48^{\prime} 7^{\prime \prime} \mathrm{E}$ ) located about six $\mathrm{km}$ away from the forest site across the Sekonyer river (Fig. 1). The forest site, locally known as Pesalat, was undrained and maintained in pristine conditions. It was dominated by Dipterocarpaceae (Shorea ovalis, Vatica oblongifolia), Tetrameristaceae (Tetramerista glabra) and Anacardiaceae (Gluta rengas). The forest floor was uneven with the presence of $20-30 \mathrm{~cm}$ tall hummocks around tree trunks and hollows in between hummocks. The hummocks which are formed of roots, accumulated decomposing litter and peat, remain above the water surface throughout the year whereas the water table level in hollows is much closer to the soil surface.

The two oil palm plantations of one (OP2012) and 6 (OP2007) year old were smallholder plantations (1-1.5 ha) located near the village of Bedaun. Lowering of the water table to improve palm productivity was implemented by excavating 57 and $100 \mathrm{~cm}$ deep drainage canals around the OP2012 and OP2007 plantations, respectively. Inorganic fertilizers were spread by hand to the plantations every three months, for an annual total of about $120-150 \mathrm{~kg} \mathrm{~N}, 70-85 \mathrm{~kg}$ $\mathrm{P}$ and 100-120 kg K ha ${ }^{-1}$ (Swails et al. 2017). Weeds and pests were controlled by regularly applying herbicides within a 1-2 $\mathrm{m}$ radius from the palms. Both plantations were converted from primary forest which was cleared in 1989 by slashing and burning after extraction of the valuable timber. After the deforestation, shifting cultivation was practiced in the area for about 20 years with several cycles alternating 2 years of cropping (either rice or horticulture crops) and longer fallow periods. Thus, the sites underwent several land clearing fires, five at least. The OP2012 site was planted with palms in 2012 at a density of 153 palms ha ${ }^{-1}$ (about $8.7 \mathrm{~m}$ between palms in a triangular design). Palms were planted at the OP2007 site in 2007 at a density of 196 palms ha $^{-1}$ (about $7.7 \mathrm{~m}$ between palms in a triangular design). 

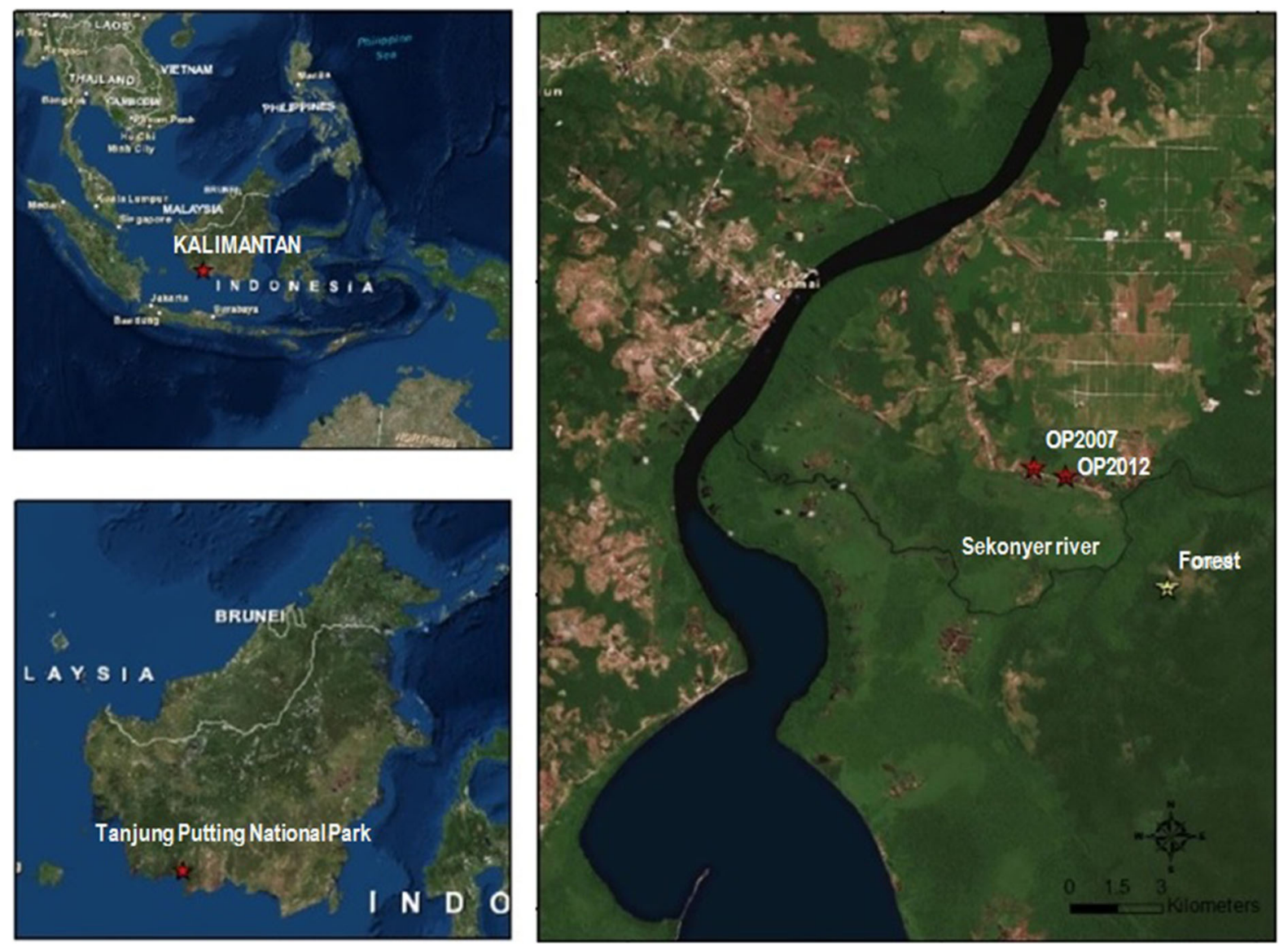

Fig. 1 Location of the research area in Central Kalimantan, Indonesia. The sites include a primary peat swamp forest inside Tanjung Puting national park (yellow star), a 1 (OP2012) and a 6 (OP2007) year old oil palm plantation on peat (red stars). (Color figure online)

\section{Experimental design}

At each of the three study sites a $100 \times 50 \mathrm{~m}$ area was delineated in which two $100 \times 10 \mathrm{~m}$ plots about $30 \mathrm{~m}$ apart were established; one to serve as a control and the second for trenching (Fig. 2). Control and trenched plots were used to measure total soil respiration (SRt) and heterotrophic respiration (SRh), respectively. The $2 \times 2 \mathrm{~m}^{2}$ trenches were made using a chainsaw in June 2012; one year prior to the beginning of the measurements. They were one meter deep (depth at which no coarse roots were observed) and $0.2 \mathrm{~m}$ wide. We lined the inner side of the trenches with construction plastic and subsequently backfilled them. To ensure that new vegetation did not develop in the trenched plots, clipping at the surface was conducted monthly, a few days prior to $\mathrm{CO}_{2}$ efflux measurement.
Considering the possibility of reinvasion of roots into root-free zones (Sayer and Tanner 2010) we recut the trenches in December 2013 (one and half year after initial trenching) at the forest and OP2012 sites. Retrenching was not conducted at the OP2007 due to refusal by the owner who was concerned about potential damage to the plantation. Re-trenching was performed similarly to initial trenching and new construction plastic lining the trenches were installed.

Each control plot was divided into twelve subplots comprising each two spatial positions. In the forest these positions coincided with a hummock surrounding a tree (CT) and a hollow in between trees (FT). In the oil palm plantations, the spatial positions were stratified according to the distance to a palm, one being close to a palm (CT) and the other one far from a palm (FT). The CT position, about $0.3 \mathrm{~m}$ from the palm, is 
Fig. 2 Experimental design implemented for assessing total and heterotrophic soil respiration in the forest (top) and oil palm plantations (bottom). The collars (black circle) where total soil respiration was monitored were placed close to tree/palm and far from tree/palm in control plots (left). Those where heterotrophic soil respiration was measured were located in trenched plots (right, squares with dashed lines) and far from tree/palm to avoid root presence

\section{Forest}

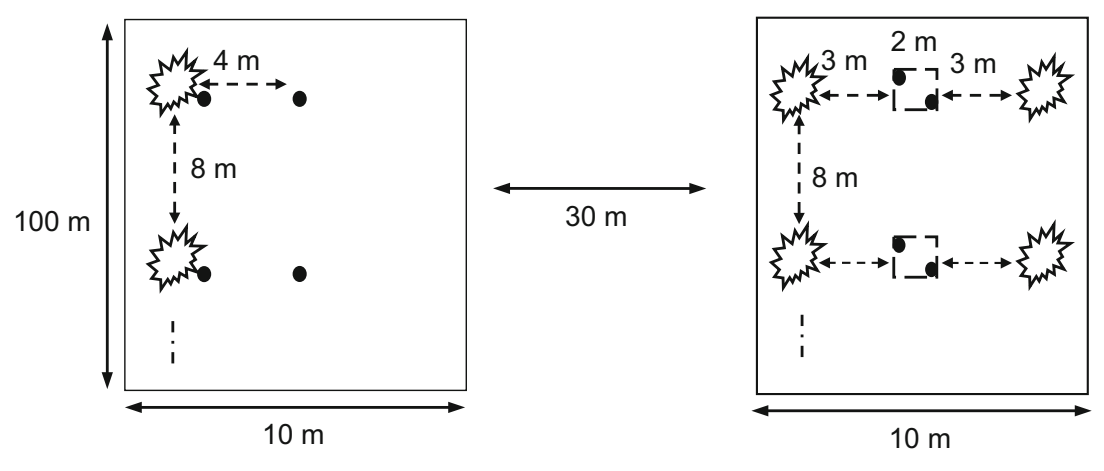

Oil palm plantations

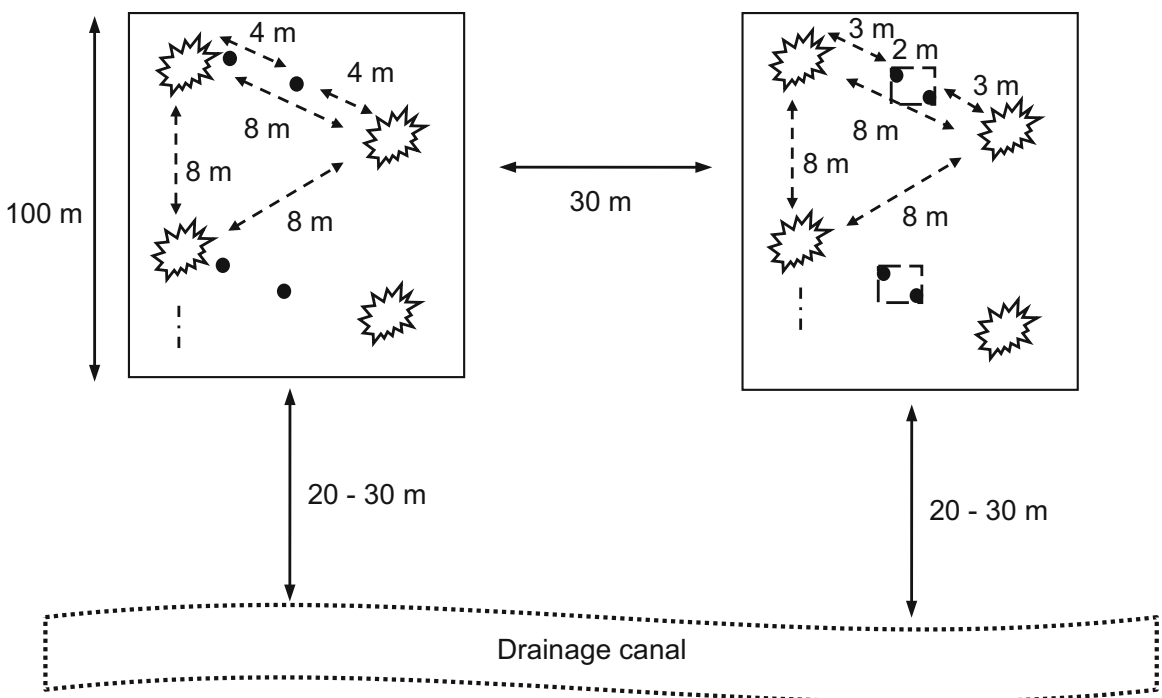

where fertilizer is usually applied and the FT position was set at mid-distance between two palms (i.e. at about $4 \mathrm{~m}$ from the palm trunk). Each trenching plot was also divided into twelve trenched subplots comprising each two sampling positions. The trenched subplots were located about $3 \mathrm{~m}$ away from trees/palms to avoid root presence and the two sampling positions inside them were chosen at random. The trenched plots did not receive fertilizers. At all sites, the distance between subplots both in control and trenched plots was around $8 \mathrm{~m}$; which is the average palm spacing in the plantations.

To minimize soil disturbance boardwalks were placed to access each measurement point. All equipment was installed at least a month before the measurements started.
Soil $\mathrm{CO}_{2}$ respiration measurement

Soil respiration was monitored monthly from June 2013 to June 2014 (over 13 months) using a portable infra-red analyzer (EGM-4 Environmental Gas Monitor) connected to a soil respiration chamber (SRC-1) (PP System, Amesburry, USA). The chamber was placed on top of a PVC collar (inner diameter of $10 \mathrm{~cm}$, height of $5 \mathrm{~cm}$ ) that was permanently inserted into the ground to a $5 \mathrm{~cm}$ depth at each sampling point. Concentrations of $\mathrm{CO}_{2}$ were recorded automatically at $4.5 \mathrm{~s}$ intervals for 1.5-2 min until reaching a constant flux rate. Since the EGM-4 connected to a SRC-1 can overestimate the flux (Pumpanen et al. 2004), the measurement was repeated trice whenever a flux rate $>65 \mathrm{~kg} \mathrm{C}$ 
ha $^{-1}$ day $^{-1}$ was read. The latest of the 3 records, usually the one with the lowest flux rate, was the value considered. The $\mathrm{CO}_{2}$ flux was calculated by the EGM from the linear increase of $\mathrm{CO}_{2}$ concentration in the headspace with time. The EGMcomputed fluxes were in agreement with the fluxes regularly recomputed manually from $\mathrm{CO}_{2}$ concentration readings. Before each measurement the collars were manually fanned in order to remove any accumulated $\mathrm{CO}_{2}$. Sampling was performed between 7:00 and 13:00 over a 2.5-4 h duration per site. Complementary experiments indicated no significant diurnal variation in soil respiration rate at the research sites. Soil respiration was also monitored more intensively following re-trenching at the forest and OP2012 sites. Measurements were conducted on days $+1,+3 /+5$ (forest/OP2012), +7 and +14 after trenching.

Mean monthly soil respiration rates were calculated for each spatial position (in the control plots only) in each treatment (control and trenched) at each site. Annual total and heterotrophic soil respiration rates were computed by integration of monthly flux rates using a linear interpolation between measurement dates for a 365 day year (Aini et al. 2015). Plot-scale total soil respiration rate was calculated as the average of the rates from the two spatial positions (FT, CT) in the forest. Field observation indicated an equal share of hummocks and hollows at the forest site. In the plantations, the proportion allocated to each position was based on the radius of fertilizer application (defined by the farmer) that likely coincides with the active rooting zone of the palms. In the OP2012 and OP2007 the fertilizer was usually applied inside a 1 and $2 \mathrm{~m}$ radius circle around the palms, respectively. Using the palm density we calculated that in the OP2012 the close to and far from palm areas represented, respectively, 9 and $91 \%$ of the plot surface. In the OP2007 these two areas represented, respectively 35 and $65 \%$ of the plot surface. We conducted a sensitivity analysis testing how changes in our estimates of the proportion that the CT area occupies in the plot impact upon annual total soil respiration and the contribution of heterotrophic respiration to total respiration. The contribution of heterotrophic to total soil respiration was computed from cumulative values before re-trenching, after retrenching and for the whole monitoring period.
Environmental parameters and soil properties

Rainfall was monitored daily using a weather station (Delta Ohm HD2013R, Padova, Italy) installed in the OP2012. Soil temperature was measured at a $10 \mathrm{~cm}$ depth using a soil thermometer probe (Reotemp Digital TM99-A, USA) and air temperature was manually recorded using a digital thermometer placed in the shade at about $1 \mathrm{~m}$ from the ground. The water table depth was measured in PVC wells $(2.5 \mathrm{~cm}$ in diameter, $2 \mathrm{~m}$ in length) inserted permanently into the peat. A measuring stick was lowered into the well until its end touched the water surface. The water table depth was computed by subtracting the depth of the measuring point above ground surface from the depth recorded between the water surface to the measuring point on top of the well. Each of these parameters was measured at each respiration collar and concomitantly with $\mathrm{CO}_{2}$ fluxes. The soil gravimetric water content, bulk density and water-filled pore space (WFPS) were also determined monthly by collecting six soil samples using a metallic ring $(8.15 \mathrm{~cm}$ in diameter $\times 6 \mathrm{~cm}$ in height). Three replicates were collected at each spatial position (CT, FT) from outside of the soil respiration subplots to minimize disturbance. Soil moisture was therefore not monitored inside trenched subplots. Soil moisture was calculated from the fresh mass measured in the field and the dry mass after oven-drying at $60^{\circ}$ for 2-3 days. Bulk density was calculated from the dry mass of soil and the ring volume. The WFPS was computed using the formula by Linn and Doran (1984) using a default particle density of $1.4 \mathrm{~g} \mathrm{~cm}^{-3}$, representative for Indonesian ombrogeneous peats (Driessen and Rochimah 1976).

Litterfall was collected monthly in the forest using twelve permanent litter baskets (area $=0.28 \mathrm{~m}^{2}$ ) randomly positioned on trees. The litter was subsequently oven-dried at $60{ }^{\circ} \mathrm{C}$ for two days and weighted. Annual litterfall rate was calculated by summing monthly litterfall over the thirteen month monitoring period and annualizing to twelve months. Annual litterfall was converted to a carbon rate using a $\mathrm{C}$ fraction of $48 \%$ (Aalde et al. 2006). At the end of the experiment the density of roots was measured in the control plots from six replicates per spatial position (CT and FT) by using the above described ring inserted to a $6 \mathrm{~cm}$ depth. Root samples were washed, sorted into dead and live roots and oven-dried at $60^{\circ}$ 
for 2-3 days to determine the dry mass. Their density was calculated from their dry mass and the corer area. Finally at each site, we collected three composite soil samples (CT and FT confounded) at 0-6 cm depth for soil chemical analysis at the forestry faculty of Bogor agricultural institute (IPB). The $\mathrm{pH}$ was determined in water and $1 \mathrm{M} \mathrm{KCl} \mathrm{(1:1} \mathrm{ratio)} \mathrm{(Thomas} \mathrm{1996).}$ Exchangeable cations $\left(\mathrm{Ca}^{2+}, \mathrm{Mg}^{2+}, \mathrm{Na}^{+}\right.$and $\left.\mathrm{K}^{+}\right)$, Cation Exchange Capacity (CEC) and base saturation were determined by displacement from the soil colloids with ammonium acetate adjusted to $\mathrm{pH} 7$ (Pansu et al. 2001). Concentrations of $\mathrm{C}$ and $\mathrm{N}$ of dried peat samples were analyzed using an induction furnace $\mathrm{C} / \mathrm{N}$ analyzer (LECO Corporation, St. Joseph MI, USA) from 9 to 17 replicates per site taken from the top $15 \mathrm{~cm}$ of the soil profile.

\section{Statistical analysis}

Statistical analysis was performed using the software Infostat (Di Rienzo et al. 2014). A probability threshold of 0.05 was used to determine the significance of the effects. All of the measured variables were tested for normality of distribution of residuals using the Shapiro-Wilks test. Averages of environmental parameters and soil respiration rates were compared across trenched plots, CT and FT positions in control plots within a site. They were also compared across sites within trenched plots, CT and FT positions in control plots. The difference in average of the variables between dry and wet months was tested considering a month as dry when its cumulative rainfall rate was $<100 \mathrm{~mm}$. For multiple comparisons, ANOVA and the non-parametric Kruskal-Wallis test were applied for normally and non-normally distributed data, respectively. For single comparisons, the $t$ test or non-parametric Mann-Whitney test were applied for normal and non-normally distributed data, respectively. Annual cumulative soil respiration $\pm \mathrm{s}-$ tandard error which did not overlap were considered significantly different between trenched plots, CT and FT positions in control plots within a site; or between sites within trenched plots, CT and FT positions in control plots. The same assumption was made for the contribution of SRh to SRt within a site before retrenching, after re-trenching and for the whole monitoring period.

Relationships between soil respiration and environmental variables or between environmental variables themselves were analyzed using simple and multiple linear or non-linear regression models. Only significant relationships with an $\mathrm{R}^{2}>0.35$ are presented.

\section{Results}

Soil properties

The peat depth differed between sites following the order: forest $>$ OP2007 > OP2012 (Table 1). As typically reported for ombrotrophic peats, the soil exhibited low $\mathrm{pH}$ and high CEC values. The sites did not display a significant difference in soil $\mathrm{C}$ content; however, the plantations had a lower $\mathrm{N}$ content $(\mathrm{P}=0.0001)$ and higher $\mathrm{C} / \mathrm{N}$ ratio $(\mathrm{P}=0.0006)$ than the forest. The bulk densities were low as the result of a high pore space volume. These were significantly $(\mathrm{P}<0.0001)$ increased by the conversion to plantation, at both spatial positions (CT and FT), as the result of drainage and compaction during land preparation. Root density was higher in the OP2012 than in the OP2007 at the CT position $(\mathrm{P}=0.0043)$. At the FT position it was higher in the OP2012 and forest than in the OP2007 $(\mathrm{P}=0.0136)$. The root density was higher CT than FT at the OP2012 site only $(\mathrm{P}=0.026)$.

\section{Environmental parameters}

Air temperature was the highest at the OP2012 plantation, whereas the OP2007 and forest exhibited similar temperatures $(\mathrm{P}<0.0001)$ (Table 1$)$. The two CT and FT spatial positions had a same temperature at all sites while the trenched plots (T) in the forest and OP2012 were significantly warmer than the control plots $(\mathrm{P}<0.0001)$. The air temperature remained relatively stable throughout the year in the forest and OP2007, with average values between $28-32{ }^{\circ} \mathrm{C}$ and 26-34 ${ }^{\circ} \mathrm{C}$, respectively (Fig. 3a). Abrupt increases in temperature with values $>40{ }^{\circ} \mathrm{C}$ were recorded at the OP2012 in September, October and December 2013. Mean peat temperature was the highest in the OP2012, followed by the OP2007 and the forest $(\mathrm{P}<0.0001)$. In the OP2012 the temperature was significantly warmer at the FT position than at the CT one $(\mathrm{P}<0.0001)$. The peat temperature in the trenched plots of the forest and OP2012 displayed higher values 
Table 1 Top 6-15 cm edaphic physical, chemical and climatic properties in the forest, 1 (OP2012) and 6 (OP2007) year old oil palm plantations in Central Kalimantan, Indonesia
CT designates the close to tree position and FT the far from tree position in the control plots; $\mathrm{T}$ designates the trenched plots. Data are presented as mean $\pm \mathrm{SE}$

(n). Letters a, b, c indicate a significant difference between sites within trenched plots, CT and FT positions in control plots; $\alpha$, $\beta, \gamma$ a significant difference between trenched plots, CT and FT in control plots within a site. No letters are displayed in the absence of a significant difference

$C E C$ : cation exchange capacity

\begin{tabular}{|c|c|c|c|}
\hline Parameter & Forest & OP2012 & OP2007 \\
\hline Peat depth $(\mathrm{cm})$ & $155.3 \pm 5.9(18)^{\mathrm{c}}$ & $29.6 \pm 3.6(9)^{\mathrm{a}}$ & $46.0 \pm 3.6(9)^{\mathrm{b}}$ \\
\hline $\mathrm{pHH}_{2} \mathrm{O}$ & $3.9 \pm 0.0(3)$ & $3.7 \pm 0.1(3)$ & $3.8 \pm 0.0(3)$ \\
\hline $\mathrm{pH}_{\mathrm{KCL}}$ & $2.9 \pm 0.1(3)$ & $2.9 \pm 0.0(3)$ & $2.9 \pm 0.1(3)$ \\
\hline Base saturation (\%) & $7.9 \pm 0.1(3)$ & $7.2 \pm 1.7(3)$ & $6.3 \pm 0.1(3)$ \\
\hline CEC $\left(\mathrm{cmolc} \mathrm{kg}^{-1}\right)$ & $98.3 \pm 0.4(3)$ & $80.7 \pm 12.1$ & $96.0 \pm 0.9(3)$ \\
\hline Total C (\%) & $48.5 \pm 1.2(17)$ & $45.1 \pm 1.9(12)$ & $47.4 \pm 5.3(9)$ \\
\hline Total N (\%) & $1.6 \pm 0.1(17)^{\mathrm{b}}$ & $1.2 \pm 0.1(12)^{\mathrm{a}}$ & $0.9 \pm 0.1(9)^{\mathrm{a}}$ \\
\hline $\mathrm{C} / \mathrm{N}$ & $31.5 \pm 2.3(17)^{\mathrm{a}}$ & $39.9 \pm 2.6(12)^{\mathrm{b}}$ & $57.1 \pm 9.6(9)^{\mathrm{b}}$ \\
\hline \multicolumn{4}{|c|}{ Bulk density $\left(\mathrm{g} \mathrm{dm} \mathrm{cm}^{-3}\right)$} \\
\hline $\mathrm{CT}$ & $0.15 \pm 0.01(39)^{\mathrm{a}}$ & $0.32 \pm 0.03(36)^{\mathrm{b}}$ & $0.27 \pm 0.01(39)^{\mathrm{b}}$ \\
\hline FT & $0.18 \pm 0.02(39)^{\mathrm{a}}$ & $0.34 \pm 0.02(36)^{\mathrm{b}}$ & $0.34 \pm 0.02(39)^{\mathrm{b}}$ \\
\hline \multicolumn{4}{|l|}{ Roots $\left(\mathrm{Mg} \mathrm{dm} \mathrm{ha}{ }^{-1}\right)$} \\
\hline $\mathrm{CT}$ & $3.6 \pm 0.5(6)^{\mathrm{ab}}$ & $4.9 \pm 0.3(6)^{\mathrm{b} \beta}$ & $2.2 \pm 0.5(6)^{\mathrm{a}}$ \\
\hline FT & $3.5 \pm 0.7(4)^{\mathrm{b}}$ & $3.7 \pm 0.2(6)^{\mathrm{b} \alpha}$ & $1.8 \pm 0.4(6)^{\mathrm{a}}$ \\
\hline \multicolumn{4}{|l|}{ Air temperature $\left({ }^{\circ} \mathrm{C}\right)$} \\
\hline $\mathrm{CT}$ & $29.4 \pm 0.2(131)^{\mathrm{a} \alpha}$ & $35.6 \pm 0.4(142)^{\mathrm{b} \alpha}$ & $29.8 \pm 0.3(149)^{\mathrm{a}}$ \\
\hline FT & $29.4 \pm 0.1(130)^{\mathrm{a} \alpha}$ & $35.3 \pm 0.4(144)^{\mathrm{b} \alpha}$ & $29.5 \pm 0.3(148)^{\mathrm{a}}$ \\
\hline $\mathrm{T}$ & $30.0 \pm 0.2(285)^{\mathrm{a} \beta}$ & $39.6 \pm 0.4(272)^{\mathrm{b} \beta}$ & $29.9 \pm 0.2(228)^{\mathrm{a}}$ \\
\hline \multicolumn{4}{|l|}{ Peat temperature $\left({ }^{\circ} \mathrm{C}\right)$} \\
\hline $\mathrm{CT}$ & $25.3 \pm 0.2(131)^{\mathrm{a} \alpha}$ & $26.9 \pm 0.1(142)^{\mathrm{c} \alpha}$ & $6.2 \pm 0.1(149)^{\mathrm{b}}$ \\
\hline FT & $25.5 \pm 0.1(132)^{\mathrm{a} \alpha}$ & $27.4 \pm 0.1(144)^{\mathrm{c} \beta}$ & $26.1 \pm 0.1(148)^{\mathrm{b}}$ \\
\hline $\mathrm{T}$ & $25.7 \pm 0.0(267)^{\mathrm{a} \beta}$ & $29.3 \pm 0.1(283)^{\mathrm{c} \gamma}$ & $26 \pm 0.1(239)^{\mathrm{b}}$ \\
\hline \multicolumn{4}{|c|}{ Water table level $(\mathrm{cm})$} \\
\hline $\mathrm{CT}$ & $-25.3 \pm 1.5(136)^{\mathrm{b} \gamma}$ & $-27.2 \pm 1.7(156)^{\mathrm{b}}$ & $-37.9 \pm 2.6(151)^{\mathrm{a} \alpha}$ \\
\hline FT & $-13.8 \pm 1.4(105)^{\mathrm{c} \beta}$ & $-24.2 \pm 1.9(120)^{\mathrm{b}}$ & $-34.0 \pm 2.6(135)^{\mathrm{a} \alpha}$ \\
\hline $\mathrm{T}$ & $-4.7 \pm 0.9(249)^{\mathrm{c} \alpha}$ & $-25.8 \pm 1.5(262)^{\mathrm{b}}$ & $-44.7 \pm 1.8(153)^{\mathrm{a} \beta}$ \\
\hline \multicolumn{4}{|c|}{ Water filled pore space $(\%)$} \\
\hline $\mathrm{CT}$ & $40.0 \pm 2.8(39)^{\alpha}$ & $46.9 \pm 3.1(36)$ & $44.8 \pm 2.4(39)^{\alpha}$ \\
\hline FT & $60.7 \pm 3.1(39)^{\mathrm{b} \beta}$ & $50.5 \pm 2.9(36)^{\mathrm{a}}$ & $60.1 \pm 4.0(39)^{\mathrm{b} \beta}$ \\
\hline
\end{tabular}

than their respective control plots $(\mathrm{P}=0.0079$ and $\mathrm{P}<0.0001$ ); following the same trend as air temperature. The peat temperature was stable in the forest over the monitoring period whilst more fluctuation was observed in the plantations (Fig. 3b). A high average peat temperature was recorded at both plantations in October.

The rainfall during the monitoring period of $2658 \mathrm{~mm}$ year $^{-1}$ was above long-term records. Dry months (rainfall $<100 \mathrm{~mm} \mathrm{month}^{-1}$ ) occurred in June, September and October 2013 (Fig. 4). The water table was significantly deeper in the OP2007 than in the forest in control and trenched plots $(\mathrm{P}<0.001)$ while the OP2012 displayed intermediary values except at the CP position where the level was similar to that in the forest. The observed difference in water table level between the two plantations reflects their difference in drainage canal depth $(57$ and $100 \mathrm{~cm}$ in the OP2012 and OP 2007, respectively). The water table was significantly influenced by the spatial position in the forest only, with a lower level in hollows (FT) than in hummocks $(\mathrm{CT})(\mathrm{P}<0.0001)$. In the OP2007 the water table was deeper in the trenched than in the control plots whereas the opposite was true in the forest $(\mathrm{P}<0.0001)$. Over the experimental period the average water table level fluctuated between -39 and $8 \mathrm{~cm}$ in the forest, -68 and $1 \mathrm{~cm}$ in the OP2012 and -99 and $0 \mathrm{~cm}$ in the OP2007 (Fig. 4, left). The water table level was on average lower during dry months than during wetter months 

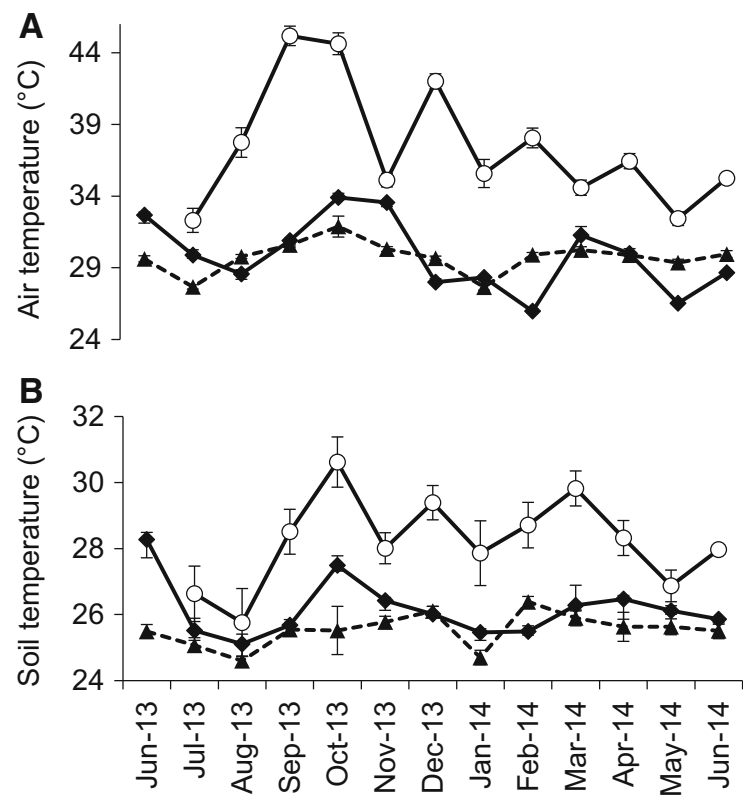

Fig. 3 Monthly air (A) and soil temperature (B) (mean \pm SE, $\mathrm{n}=48$ ) in the forest (dashed line, solid triangle), OP2012 (solid line, open circle) and OP2007 (solid line, solid diamond) plantations on peat in Central Kalimantan, Indonesia

$(\mathrm{P}<0.003)$ at all sites, in trenched and control plots. At the plantations it decreased linearly with decreasing rainfall $\left(\mathrm{R}^{2}=0.56\right.$ and 0.46 in the OP2012 and OP2007, respectively; $\mathrm{P}<0.0001$ ). The WFPS was similar across sites at the CT position but at the FT position it was significantly lower in the OP2012 than at the two other sites indicating drier conditions $(\mathrm{P}=0.039)$. In the forest and OP2007 the WFPS was significantly higher FT than CT $(\mathrm{P}<0.001$ and $\mathrm{P}=0.001$, respectively). Throughout the year the WFPS oscillated in a similar fashion at the CT and FT positions in the OP2012 (Fig. 4b, right). On the contrary in the forest and OP2007 the WFPS remained relatively stable close to tree but fluctuated substantially far from tree (Fig. 4a, c). The WFPS was on average lower in dry than in wet months, at both spatial positions in the plantations $(\mathrm{P}<0.03)$. Monthly WFPS and rainfall were significantly but very poorly related $\left(\mathrm{R}^{2}=0.02\right)$.

Annual litterfall production in the forest amounted to $8.7 \pm 0.4 \mathrm{Mg} \mathrm{dm} \mathrm{ha}^{-1}$ year $^{-1}$ or $4.2 \pm 0.2 \mathrm{Mg} \mathrm{C}$ $\mathrm{ha}^{-1}$ year $^{-1}$. Litterfall shifted from low rates in November-December 2013 to high rates in January-
February 2014 (Fig. 5). The litterfall rate was on average lower in months following a dry month than in months following a wet month $(\mathrm{P}=0.018)$.

Soil respiration

The average total soil respiration rate (SRt) was significantly higher in the OP2007 than at the two other sites at the CT position $(\mathrm{P}<0.0001)$ but higher in the forest than in the plantations at the FT position $(\mathrm{P}=0.0042)$ (Table 2). In both plantations SRt was higher at the CT than at the FT position $(\mathrm{P} \leq 0.0024)$. The soil heterotrophic respiration rate (SRh) was significantly higher in the OP2012 than at the other sites $(\mathrm{P}=0.0001)$. It was lower than $\mathrm{SRt}$ at both spatial positions in the forest and OP2007 ( $\mathrm{P}<0.0001)$; in the OP2012 it was lower than SRt at the CT position only $(\mathrm{P}=0.0153)$.

High emission rates in SRt at the FT position were observed in the forest and OP2012 in September and October (Fig. 6A, B) whereas such a pattern was not apparent in the OP2007. In the latest SRt at the CT position was uneven with high rates recorded in August, January, February and April. Heterotrophic respiration remained relatively stable throughout the monitoring period but increased in the two months following re-trenching in the forest and OP2012, suggesting a potential exacerbation of SRh induced by the disturbance. SRh was significantly lower before retrenching in December than during the two months following retrenching $(\mathrm{P}=0.0046$ and 0.0055 in the forest and OP2012, respectively). The contribution of $\mathrm{SRh}$ to SRt increased following re-trenching at both sites (Fig. 7). This increase is very apparent in the days following the trenching event until a month afterwards. The contribution of SRh to SRt went back to pre-re-trenching levels after April in the OP2012 whereas in the forest it remained higher than pre retrenching levels until the end of the experiment.

Annual cumulative SRt rate at the plot scale was the highest in the OP2007 followed by the forest and OP2012 (Table 2) while annual cumulative SRh rate followed the order OP2012 > forest $>$ OP2007. From these results the contribution of SRh to SRt was the lowest in the OP2007 and forest; the highest in the OP2012. Nevertheless, given the apparent increase in $\mathrm{SRh}$ and in the contribution of SRh to SRt (\%SRh) following re-trenching, we assume the \%SRh before re-trenching to be more accurately representative of 

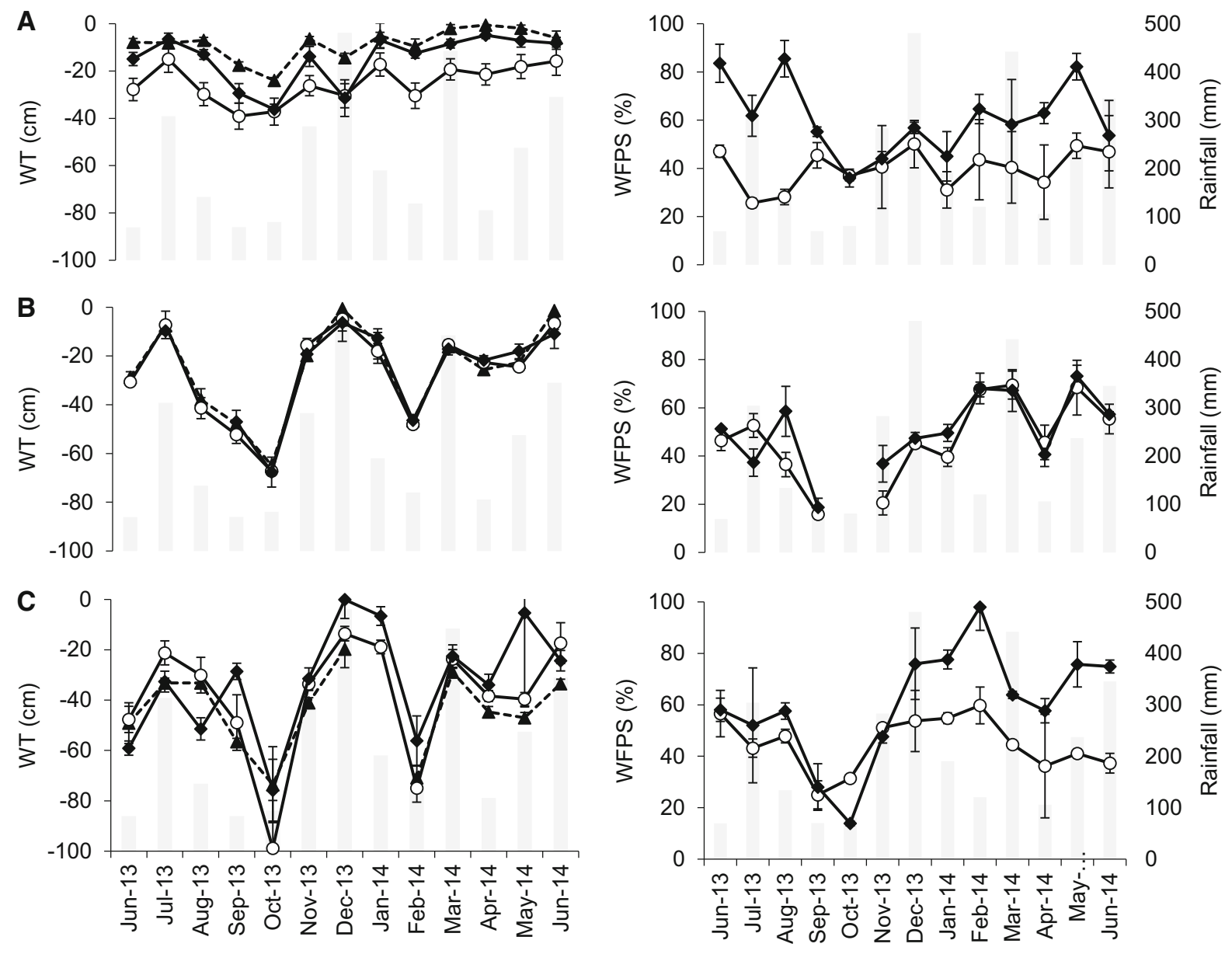

Fig. 4 Monthly water table level (WT) (left) and water-filled pore space (WFPS, right) in the forest (A), OP2012 (B) and OP2007 (C) plantations; close to tree (CT, solid line, open circle), far from tree (FT, solid line, solid diamond) and in the trenched plots (dashed line, solid triangle). WT and WFPS

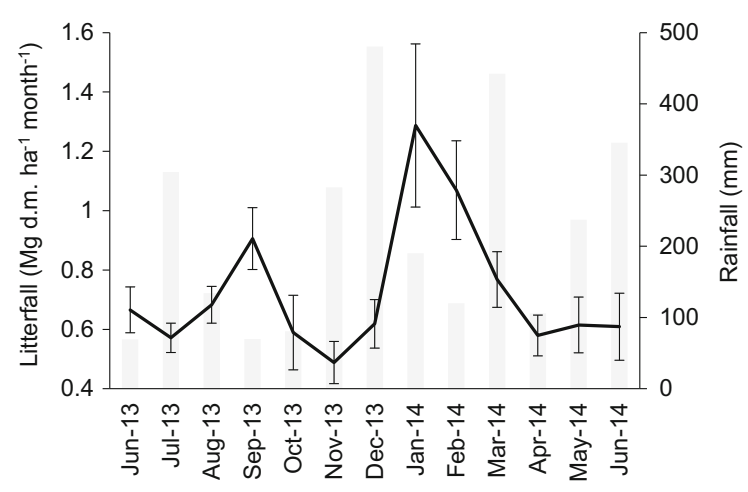

Fig. 5 Monthly litterfall rate (solid line) in the forest at Tanjung Puting, Central Kalimantan, Indonesia. Error bars are standard error of the mean $(\mathrm{n}=12)$. Grey bars are monthly rainfall rates values are mean $\pm \mathrm{SE}$. For the WT, $\mathrm{n}=12$ at the CT and FT positions, $n=24$ in the trenched plots. For the WFPS, $n=3$ at the CT and FT positions. The WFPS was not measured in the trenched plots to avoid disturbance. Grey bars are monthly rainfall rates

actual values in the forest and OP2012. These contributions applied to annual SRt rate indicate that annual $\mathrm{SRh}_{\text {adjusted }}$ rate was the highest at the OP2012 youngest plantation $\left(9.6 \pm 0.8 \mathrm{Mg} \mathrm{C} \mathrm{ha}^{-1}\right.$ year $\left.^{-1}\right)$, followed by the OP2007 plantation $(8.4 \pm 0.3 \mathrm{Mg} \mathrm{C}$ $\left.\mathrm{ha}^{-1}\right)$, and the forest $\left(7.1 \pm 0.4 \mathrm{Mg} \mathrm{C} \mathrm{ha}^{-1}\right)$.

In the OP2012 neither plot-scale annual SRt nor the $\% \mathrm{SRh}$ were significantly affected by varying the proportion that the $\mathrm{CT}$ area occupies in the plot (Fig. 8A). Contrastingly, given the large difference in soil respiration rate between the $\mathrm{CT}$ and FT positions in the OP2007, the share of the CT area had a substantial impact on both annual SRt rate and the \%SRh (Fig. 8B). Varying the CT proportion from 5 to $50 \%$ implied a $43 \%$ increase and a $30 \%$ decrease 
Table 2 Annual average, cumulative soil respiration rates and contributions of heterotrophic to total soil respiration (\%SRh) in the forest, 1 (OP2012), and 6 (OP2007) year old oil palm plantations. Total respiration rates (SRt) are presented at the close to tree (CT), far from tree (FT) positions and at the plot scale*. Heterotrophic respiration rates $(\mathrm{SRh})$ are presented at the plot scale only since no trees were present in the subplots.

\begin{tabular}{|c|c|c|c|c|c|c|c|}
\hline $\begin{array}{l}\text { Land } \\
\text { use }\end{array}$ & $\begin{array}{l}\text { Soil respi. } \\
\text { component }\end{array}$ & $\begin{array}{l}\text { Spatial } \\
\text { position }\end{array}$ & $\begin{array}{l}\mathrm{CO}_{2} \\
\left(\mathrm{~kg} \mathrm{C} \mathrm{ha}^{-1} \mathrm{day}^{-1}\right)\end{array}$ & $\begin{array}{l}\mathrm{CO}_{2} \\
\left(\mathrm{Mg} \mathrm{C} \mathrm{ha}^{-1} \text { year }^{-1}\right)\end{array}$ & $\% \mathrm{SRh}$ & $\begin{array}{l}\% \mathrm{SRh}_{\text {Before re- }} \\
\text { trenching }\end{array}$ & $\begin{array}{l}\mathrm{SRh}_{\text {adjusted }} \\
\left(\mathrm{Mg} \mathrm{C} \mathrm{ha}^{-1} \text { year }^{-1}\right)\end{array}$ \\
\hline \multirow[t]{4}{*}{ Forest } & \multirow[t]{3}{*}{ SRt } & $\mathrm{CT}$ & $36.1 \pm 2.0(182)^{\mathrm{a} \beta}$ & $13.1 \pm 0.5$ & & & \\
\hline & & FT & $34.2 \pm 1.6(183)^{\mathrm{b} \beta}$ & $12.6 \pm 0.4$ & & & \\
\hline & & Plot & $35.1 \pm 1.3(365)$ & $12.9 \pm 0.3^{\mathrm{b}}$ & & & \\
\hline & $\mathrm{SRh}$ & Plot & $25.5 \pm 1.0(405)^{\mathrm{a} \alpha}$ & $9.5 \pm 0.3^{\mathrm{b}}$ & $73.9 \pm 3.2^{\mathrm{b}}$ & $55.1 \pm 2.8$ & $7.1 \pm 0.4^{\mathrm{a}}$ \\
\hline \multirow[t]{4}{*}{ OP2012 } & \multirow[t]{3}{*}{ SRt } & $\mathrm{CT}$ & $33.7 \pm 1.5(210)^{\mathrm{a} \beta}$ & $12.0 \pm 0.4$ & & & \\
\hline & & FT & $30.3 \pm 1.7(212)^{\mathrm{a} \alpha}$ & $11.6 \pm 0.5$ & & & \\
\hline & & Plot & $30.6 \pm 1.6(422)$ & $11.7 \pm 0.4^{\mathrm{a}}$ & & & \\
\hline & $\mathrm{SRh}$ & Plot & $29.8 \pm 1.1(405)^{\mathrm{b} \alpha}$ & $11.7 \pm 0.3^{\mathrm{c}}$ & $100.0 \pm 4.7^{\mathrm{c}}$ & $82.5 \pm 5.7$ & $9.6 \pm 0.8^{\mathrm{c}}$ \\
\hline \multirow[t]{4}{*}{ OP2007 } & \multirow[t]{2}{*}{ SRt } & $\mathrm{CT}$ & $54.5 \pm 2.4(155)^{\mathrm{b} \gamma}$ & $20.5 \pm 0.6$ & & & \\
\hline & & FT & $28.1 \pm 1.3(153)^{\mathrm{a} \beta}$ & $10.2 \pm 0.3$ & & & \\
\hline & SRt & Plot & $37.3 \pm 1.2(138)$ & $13.8 \pm 0.3^{c}$ & & & \\
\hline & $\mathrm{SRh}$ & Plot & $24.2 \pm 1.0(287)^{\mathrm{a} \alpha}$ & $8.4 \pm 0.3^{\mathrm{a}\left(\mathrm{b}^{* * * *}\right)}$ & $61.0 \pm 2.3^{\mathrm{a}}$ & $-{ }^{* *}$ & $-{ }^{* * *}$ \\
\hline
\end{tabular}

$*$ In the forest $\mathrm{SRt}_{\mathrm{Plot}}=50 \% \mathrm{SRt}_{\mathrm{CT}}+50 \% \mathrm{SRt}_{\mathrm{FT}}$; in the OP2012 SRt $\mathrm{Slot}=9 \% \mathrm{SRt}_{\mathrm{CT}}+91 \% \mathrm{SRt}_{\mathrm{FT}}$; in the OP2007 $\mathrm{SRt} \mathrm{Plot}=35 \%$ $\mathrm{SRt}_{\mathrm{CT}}+65 \% \mathrm{SRt}_{\mathrm{FT}}$. Letters a, b, c indicate a significant difference between sites within trenched plots, CT and FT in control plots; $\alpha, \beta, \gamma$ a significant difference between $\mathrm{SRh}, \mathrm{SRt}_{\mathrm{CT}}$ and $\mathrm{SRt}_{\mathrm{FT}}$ within a site

** The OP2007 site was not re-trenched

*** Statistic comparing SRh in the OP2007 to SRh adjusted in the forest and OP2012. Bold values highlight annual plot-scale SRt rates, $\mathrm{SRh}$ rates and \% SRh considering the most reliable estimates for the forest and OP2012

in SRt and \%SRh, respectively; for a range in SRt and $\%$ SRh of $[10.8 \pm 0.3 ; 15.4 \pm 0.4] \mathrm{Mg} \mathrm{C}^{-1}$ year $^{-1}$ and $[54.9 \pm 2.1 ; 78.4 \pm 3.4] \%$, respectively.

Relationships between soil respiration and environmental parameters

At the forest site, monthly SRt rate at both microtopographies presented a positive relationship with air temperature; a negative one with water table level (Table 3, Eq. 1-4). At the OP2012, monthly SRt rate at the FT position increased exponentially as the result of water table draw down (Eq. 5) whereas at the OP2007 the relationship was, as in the forest, linear (Eq. 6). The response of SRt to water table draw down was much less pronounced in the plantations than in the forest. At the OP2007, SRt at the FT position increased linearly with increasing peat temperature (Eq. 7), with a response less marked than that of SRt $\mathrm{FT}_{\mathrm{FT}}$ to increasing air temperature in the forest (Eq. 1). The relationship between monthly SRt rate at the FT
The $\% \mathrm{SRh}$ was computed for the whole observation period and for the period before retrenching in the forest and OP2012 $\left(\% \mathrm{SRh}_{\text {Before re-trenching }}\right)$. Annual cumulative $\mathrm{SRh}_{\text {adjusted }}$ rates

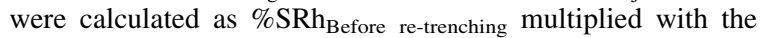
annual $\mathrm{SRt}_{\text {Plot }}$ rate. Data are mean or cumulative values $\pm \mathrm{SE}$ (n). $\mathrm{N}=12$ for annual values 


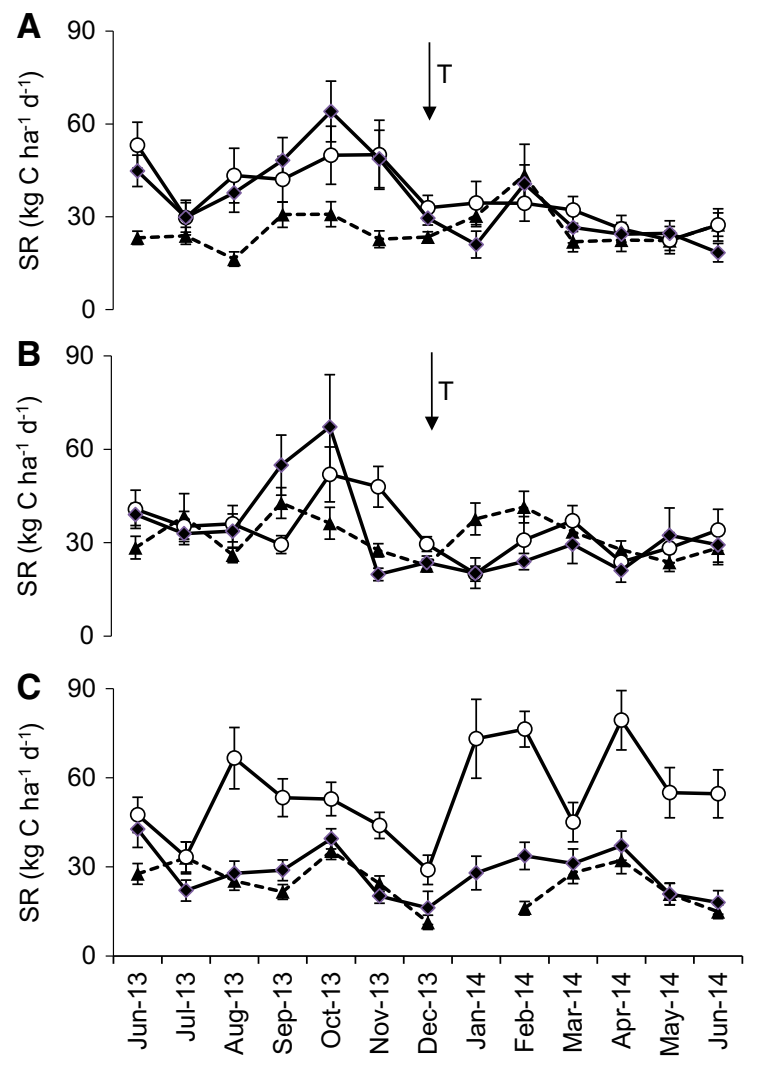

Fig. 6 Monthly soil $\mathrm{CO}_{2}$ emissions in the forest (A), OP2012 (B) and OP2007 (C) plantations. The figure presents heterotrophic respiration ( $\mathrm{SRh}$, dashed line, solid triangle $; \mathrm{n}=24)$, total soil respiration close to tree (SRt-CT, solid line, open circle $; \mathrm{n}=12$ ), and total soil respiration far from tree (SRt-FT, solid line, solid diamond; $\mathrm{n}=12$ ). Values are mean $\pm \mathrm{SE}$. The arrows with a $T$ indicate the re-trenching event

trenching method of root exclusion include disturbance effect due to trenching, influence of excised decomposing roots and differences in abiotic environment (soil moisture, temperature, presence/absence of canopy interception of precipitation, litterfall rate) between trenched and control plots (Jassal and Black 2006; Subke et al. 2006). Trenching commonly occasions an initial flush of $\mathrm{CO}_{2}$ efflux and prolonged increased $\mathrm{CO}_{2}$ flux rates resulting from the decomposition of the severed roots (Hanson et al. 2000). The timing and magnitude of SRh exacerbation are sitespecific and dependent on ecosystem type, root decay rate, climate, etc. (Subke et al. 2006). Sayer and Tanner (2010) estimated that the decomposition of residual roots dominated $\mathrm{SRh}$ over 7 months after trenching in a tropical moist forest of Panama. Given that organic matter decay rates are lower in peat
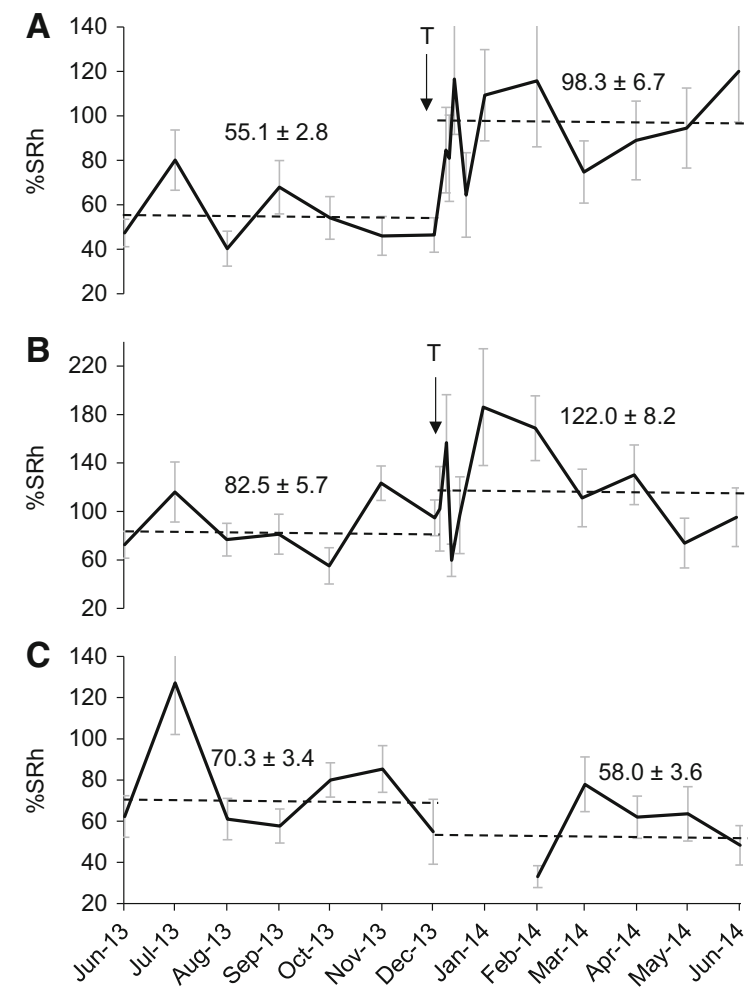

Fig. 7 Monthly contribution of heterotrophic respiration to total soil respiration $(\% \mathrm{SRh})$ in the forest $(\mathbf{A}), \mathrm{OP} 2012(\mathbf{B})$ and OP2007 (C) plantations. Mean \pm SE are calculated from 48 collars. The arrow indicates the re-trenching event. Daily contributions following re-trenching are displayed in $(\mathbf{A}, \mathbf{B})$. The dashed lines indicate $\% \mathrm{SRh}$ calculated from cumulative values of SRh and SRt before $(\mathrm{n}=7)$ and after re-trenching $(n=9)$. For comparison purposes, these are also displayed for the oldest plantation where re-trenching was not performed

swamp forests than in other types of tropical rainforests (Yule and Gomez 2009) we allowed 1 year to pass after trenching before starting collecting $\mathrm{CO}_{2}$ efflux data and assume that residual root decomposition contributed little to belowground respiration at the beginning of the experiment. Following re-trenching at two of the sites, the contribution of SRh to SRt increased drastically and more pronouncedly in magnitude and timing at the waterlogged forest than at the drained OP2012 plantation (Fig. 7). Both disturbance of microbial activity and decomposition of trenched roots may be at the origin of this increase and the difference in response between the two ecosystems is likely linked to differences in environmental conditions (soil moisture and temperature), root decomposition rates, and microbial communities. 
In order to minimize disturbance we didn't collect samples inside trenched plots for soil moisture determination and are therefore unable to evaluate whether
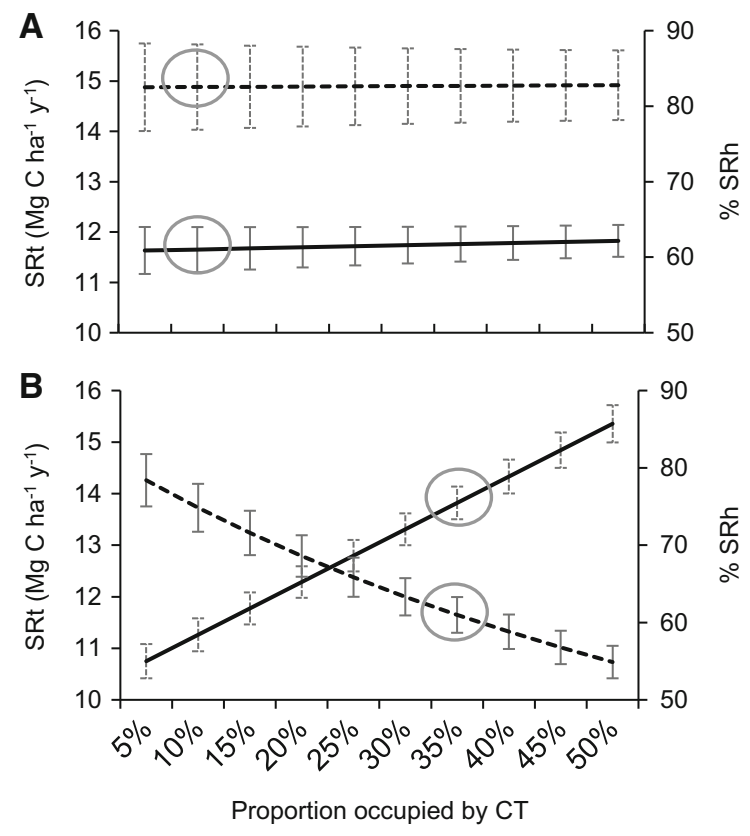

Fig. 8 Sensitivity analysis testing how the portion that the close to palm (CT) area occupies in the plot impact upon plot-scale annual total soil respiration (SRt, solid line) and the contribution of heterotrophic respiration to plot-scale annual total soil respiration (\%SRh, dashed line) in the OP2012 (A) and OP2007 (B). Bars are SE, grey circles indicate results obtained at the CT proportions selected in this study

Table 3 Relationships between average monthly total (SRt) or heterotrophic (SRh) soil respiration rate and environmental parameters in the forest (F), 1 (OP2012) and 6 (OP2007) year old oil palm plantations. CT designates the close to tree root severance may have increased soil moisture. Nonetheless the lack of significant relationship between SRt and soil moisture (Table 3) suggests that a potential difference in moisture due to root removal would not have induced $\mathrm{CO}_{2}$ flux change in a particular direction. At the forest site the average water table level was higher in the trenched than in the control plots as the result of site topographic variations. Also, temperatures were higher in trenched than in control plots. SRh rates in the forest did not exhibit a significant trend of variation with WT level or temperature changes but SRt did (Table 3). A WT level closer to the surface would decrease SRt rates while a higher temperature would have the opposite effect. Combining the over- and underestimation of SRt with respect to SRh due to, respectively, WT level and temperature differences cancels out the two effects so we consider the contribution of SRh to SRt at the forest site to be reasonably unbiased. At the OP2007, trenched plots were on average more deeply drained than control plots (due to a closer proximity to drainage canals) and at the OP2012 soil temperature was higher in trenched than in control plots. On the basis of the relationships established between SRt and the above-mentioned variables (Table 3 ), the contribution of SRh to SRt at the OP2007 and OP2012 plantations may therefore be slightly overestimated.

We evaluated SRh in trenched plots established away from trees to minimize root intrusion. Therefore

position and FT the far from tree position. The models are presented with slope (SE), intercept (SE) and level of significance

\begin{tabular}{|c|c|c|c|}
\hline Model & $\mathrm{R}^{2}$ & $\mathrm{n}$ & Eq. \\
\hline $\mathrm{SRt}_{\mathrm{F} \mathrm{FT}}=10.34 * * *(2.24) \times$ AirTemp $-268.82 * *(67.36)$ & 0.65 & 13 & 1 \\
\hline $\mathrm{SRt}_{\mathrm{F} \mathrm{CT}}=6.30 *(2.08) \times$ AirTemp $-148.49 *(61.33)$ & 0.45 & 13 & 2 \\
\hline $\mathrm{SRt}_{\mathrm{FT}}=-0.82 *(0.28) \times \mathrm{WT}+16.20 *(7.44)$ & 0.43 & 13 & 3 \\
\hline SRt $_{\mathrm{F} \mathrm{CT}}=-0.90 * *(0.27) \times \mathrm{WT}+21.88 * *(4.90)$ & 0.50 & 13 & 4 \\
\hline $\mathrm{SRt}_{\mathrm{OP} 2012 \mathrm{FT}}=23.46 * * *(3.42) \times \exp [-0.01 * *(0.0035) \times \mathrm{WT}]$ & 0.64 & 11 & 5 \\
\hline $\mathrm{SRt}_{\mathrm{OP} 2007 \mathrm{FT}}=-0.28 * *(0.09) \times \mathrm{WT}+18.54 * * *(3.57)$ & 0.47 & 13 & 6 \\
\hline SRt ${ }_{\text {OP2007 FT }}=6.27 *(2.15) \times$ SoilTemp $-135.62 *(56.3)$ & 0.44 & 13 & 7 \\
\hline $\mathrm{SRt}_{\mathrm{OP} 2007 \mathrm{CT}}=-0.07 *(0.03) \times$ Rainfall $+69.57 * * *(6.81)$ & 0.38 & 13 & 8 \\
\hline $\mathrm{SRt}_{\mathrm{OP} 2007 \mathrm{FT}}=40.61 * * *(4.08) \times \exp [-0.002 * *(0.001) \times$ Rainfall $]$ & 0.56 & 13 & 9 \\
\hline $\mathrm{SRh}_{\mathrm{F}}=15.77 * * *(3.03) \times \exp \left[0.04 *(0.01) \times\right.$ Litterfall $\left._{\text {Previous month }}\right]$ & 0.43 & 12 & 10 \\
\hline $\mathrm{SRh}_{\mathrm{F}}=1.10 *(0.44) \times$ Litterfall $+13.28 *(5.31)$ & 0.37 & 13 & 11 \\
\hline
\end{tabular}

$* \mathrm{P}<0.05, * * \mathrm{P}<0.01$, *** $\mathrm{P}<0.001$. Soil respiration is expressed in $\mathrm{kg} \mathrm{C} \mathrm{ha}^{-1} \mathrm{day}^{-1}$, water table level (WT) in $\mathrm{cm}$ with a negative value indicating a level below ground, air (AirTemp) and soil (SoilTemp) temperature in ${ }^{\circ} \mathrm{C}$; and litterfall rate (Litterfall) in kg C ha ${ }^{-1}$ day $^{-1}$ 
in the oil palm plantations where SRt was spatially stratified with lower SRt rates far from palms than close to palms (Table 2), SRh is not truly representative of plot-scale SRt. Notwithstanding the bias can be considered minimal and moderate in the OP2012 and OP2007, respectively, since the proportion that SRt close to tree represents at the plot scale is 9 and $35 \%$, respectively.

Spatial trends, temporal patterns and biochemical controls

Contrary to observations by Comeau et al. (2013) and Jauhiainen et al. (2005), hummocks and hollows in the forest respired at a similar average rate throughout the monitoring period (Fig. 6). Jauhiainen et al. (2005) indicated that high water table conditions in hollows led to reduced cumulative soil respiration. Hollows were also wetter on average than hummocks at our site and respiration was partially driven by the WT level at each of the two microtopographic positions but other parameters such as root activity seemed to be predominant in governing SRt over the WT level. In the plantations, SRt was significantly higher close to palm than at mid-distance between palms. A higher SRt rate near trunk than in the harvest path is in agreement with observations by Comeau et al. (2016) and Dariah et al. (2014) in mature plantations established on peat soils and by Nelson et al. (2014) in mature plantations on mineral soil. Nelson et al. (2014) attributed elevated respiration near trunk to inputs of organic matter in stemflow, root respiration and decomposition of root-derived organic matter since root density was higher there than elsewhere in the studied plantation. Root density in the $6 \mathrm{~cm}$ top soil was higher at the CT than at the FT position in the OP2012 but not in the OP2007. Oil palm root biomass often exhibits a radial pattern (Dariah et al. 2014; Haron et al. 1998; Nelson et al. 2014) yet this is not always the case (Oktarita et al. 2017; Ruer 1967). The difference in spatial allocation of roots between the plantations as well their difference in root density may originate from their development stage. The architecture of the oil palm root system evolves progressively from the juvenile to the adult stage towards deeper horizons and towards the periphery of the system (Jourdan and Rey 1997). We found no relationship between root density and SRt. According to Nelson et al. (2006) and Wang et al. (2008) root density does not accurately reflect root respiration and exudation activities since old coarse roots are usually less active than young fine roots. In addition regression between root density and SRt in Indonesian oil palm plantations on peat performed poorly $\left(0.003<\mathrm{R}^{2}<0.29\right)$ (Dariah et al. 2014) suggesting a weak contribution of root density to spatial variation of SRt. Based on the observation that SRt decreased linearly with increasing distance from the palm trunk up a distance of $2.5 \mathrm{~m}$ and reached a plateau afterwards, Dariah et al. (2014) proposed the use of soil $\mathrm{CO}_{2}$ efflux measured at a distance of $\geq 3 \mathrm{~m}$ from the palm to represent $\mathrm{SRh}$. Likewise Carlson et al. (2015) assigned total respiration rates measured far from tree in plantations to $\mathrm{SRh}$ rates. Our results indicate that the use of SRt rates measured at the FT position would overestimate SRh rates by $21 \%$ on average.

The sensitivity analysis testing how the share of the CT area impacted annual total soil respiration rate and the contribution of heterotrophic to total respiration highlighted the critical need for improved knowledge on spatial patterns of soil respiration in mature oil palm plantations. The thorough grid approach undertaken by Nelson et al. (2014) in a mature plantation on mineral soil showed a patchy distribution of soil respiration with highest rates observed near trunks, in the frond pile and where empty fruit bunches had been placed. These areas all together accounted for about $40 \%$ of plot-scale soil respiration. Given the existing trade-off between spatial and temporal variability, our design was limited to two spatial positions for assessing SRt. We tested it by computing plot-scale SRt from the respiration rates measured by Nelson et al. (2014) near trunks and at mid-distance between palms and the 35:65 ratio we computed for the CT:FT share in the OP2007. We obtained a result of $7.0 \mu \mathrm{mol}$ $\mathrm{CO}_{2} \mathrm{~m}^{-2} \mathrm{~s}^{-1}$ very close to the $7.7 \mu \mathrm{mol} \mathrm{CO} 2 \mathrm{~m}^{-2} \mathrm{~s}^{-1}$ flux calculated by Nelson et al. (2014), which suggests that our design and assumptions can capture reasonably well the spatial variability in SRt inherent to mature plantations.

Temporal variations in SRt were closely related to climatic variations whereas fluctuations in SRh rates were not (Table 3). This suggests that climatic changes exerted a control on root respiration via photosynthate allocation to roots rather than on soil organic matter and litter decomposition. In the forest, changes over time in $\mathrm{SRh}$ rates were linked to litter $\mathrm{C}$ inputs corroborating that soil organic matter and litter 
respiration is affected by the supply of substrate from above-ground vegetation (Metcalfe et al. 2007). The air or peat temperature response of SRt followed a linear model instead of an exponential one as found by Hirano et al. (2009) in undrained and drained peat swamp forests in Central Kalimantan. In addition our models explained $<65 \%$ of the variability of SRt versus $>92 \%$ in the study by Hirano et al. (2009). It seems therefore that the sensitivity of SRt to temperature varies substantially across peatland sites and land uses in the region. The water table level response of SRt in the forest was very similar to that measured in a Sumatran peat swamp forest (Comeau et al. 2013) but much different from the results by Hirano et al. (2009) that indicate no change in SRt when the WT was below-ground and a sharp decrease when the WT raised above-ground. In the OP plantations, SRt was linked to the WT level only at the FT position, where root water uptakes are the lowest (Nelson et al. 2006). Other studies conducted in OP plantations on peat did not find a control of WT level over SRt.

Magnitude of the emissions and land-use change implications

Annual rates of total and heterotrophic soil respiration as well as the contribution of SRh to SRt in the forest were remarkably close to the literature averages for Southeast Asian peatlands of $12.9 \pm 2.1 \mathrm{Mg} \mathrm{C}^{-1}$ year $^{-1}(\mathrm{n}=13), \quad 6.9 \pm 1.1 \mathrm{Mg} \mathrm{C} \mathrm{ha}$ year $^{-1}$ $(\mathrm{n}=14)$ and $53.5 \%(\mathrm{n}=1)$, respectively (Hergoualc'h and Verchot 2014). On the other hand, annual SRt in the plantations were about $20-30 \%$ lower than the literature average $(16.9 \pm 1.4 \mathrm{Mg} \mathrm{C}$ $\mathrm{ha}^{-1}$ year $^{-1}, \mathrm{n}=7$ ). Combining our values with upto-date literature annual rates (Database available at http://hdl.handle.net/1902.1/22351 updated with the results by Sakata et al. (2015)) brings the average soil respiration in OP plantations on peat down to $14.2 \pm 1.4 \mathrm{MgC} \mathrm{ha}^{-1}$ year $^{-1}(\mathrm{n}=13)$. The range of $\mathrm{SRt}$ rates in OP plantations on peat is wide (10.9-28.4 Mg C ha ${ }^{-1}$ year $^{-1}, \mathrm{n}=13$ ) presumably owing to differences in inherent peat properties, land use history (e.g. fire history) and management practices. Melling et al. (2013) found an increase in SRt along a chronosequence of plantations aged one, five and seven year old and attributed the rise to higher root respiration rates when the palms grow. Such an increase was also apparent in our results. Across all OP sites on peat, the correlations between SRt and either the plantation age or indicators of oxygen availability (WFPS, WT level) or soil organic matter quality (peat $\mathrm{C} / \mathrm{N}$ ratio) were not significant and very poor $\left(\mathrm{R}^{2}<0.15\right)$. A linear relationship with soil CEC was promising $\left(\mathrm{R}^{2}=0.54, \mathrm{n}=6\right)$ but significant only at the $\mathrm{P}=0.1$ level. The only soil property significantly linked to SRt in OP plantations on peat across sites was the base saturation, as already found over a wide range of land uses on peat (Hergoualc'h and Verchot 2014). The rate of SRt decreases linearly with increasing CEC $\left(\mathrm{R}^{2}=0.78, \mathrm{n}=6\right)$ that is with increasing decomposition state of the peat. Indeed the large amount of lignin-derivates formed upon decomposition provide many exchange sites (Andriesse 1988). Conversely the rate of SRt increases linearly with base saturation increase $\left(\mathrm{R}^{2}=0.91, \mathrm{n}=6\right)$, as the result of CEC decrease but also potentially of increase in $\mathrm{pH}$ and eutrophy (Andriesse 1988). These relationships explain the lower SRt rates at our plantations as compared to SRt rates measured in Malaysia by Melling et al. (2005, 2013). Smaller SRt rates than observed elsewhere in Southeast Asia may also be associated with the intense land clearing fire history at our sites. Repeated fires lead to increased recalcitrance of the peat (Könönen et al. 2016). These fires may also explain the lower soil $\mathrm{N}$ content in the plantations than in the forest (Wan et al. 2001).

Annual total soil respiration was on average similar in the forest and in the plantations. A meta-analysis conducted by Hergoualc' $h$ and Verchot (2014) indicated no consistent and overall effect of intact peat swamp forest conversion on total soil respiration, on the account of a simultaneous enhanced peat decomposition and reduced or increased root density and activity in the land covers replacing the forest. As expected annual soil heterotrophic respiration as well as the contribution of heterotrophic respiration to total soil respiration were significantly higher in the OP plantations than in the forest. The updated OP plantation average of $\% \mathrm{SRh}$ and heterotrophic soil respiration from the literature including this study amount to $72.4 \pm 6.9 \%(\mathrm{n}=4)$ and $10.4 \pm 1.4 \mathrm{Mg} \mathrm{C}$ $\mathrm{ha}^{-1}$ year $^{-1}(\mathrm{n}=20)$, respectively; close to the previously reported $73 \pm 13 \% \quad(\mathrm{n}=2)$ and $12.3 \pm 2.7 \mathrm{Mg} \mathrm{C} \mathrm{ha}^{-1} \operatorname{year}^{-1}(\mathrm{n}=9)$. A preliminary $\mathrm{C}$ budget combining the heterotrophic soil respiration rates measured at our site with literature averages for most other peat $\mathrm{C}$ in- and outputs suggests that the peat 
Table 4 Peat $\mathrm{C}$ budget calculated as the difference of annual $\mathrm{C}$ inputs from litterfall and root mortality and $\mathrm{C}$ outputs from heterotrophic soil respiration (SRh) and dissolved organic $\mathrm{C}(\mathrm{DOC})$ in the forest $(\mathrm{F})$ and oil palm plantations (OP)

\begin{tabular}{|c|c|c|c|c|c|c|c|}
\hline \multirow[t]{2}{*}{ Land use } & \multicolumn{3}{|c|}{ Soil C inputs } & \multicolumn{3}{|c|}{ Soil C outputs } & \multirow[t]{2}{*}{$\mathrm{C}$ budget } \\
\hline & Litterfall & Roots & Total & $\mathrm{SRh}$ & DOC & Total & \\
\hline $\mathrm{F}$ & $4.2 \pm 0.2$ & $1.5 \pm 0.8$ & $5.7 \pm 0.8$ & $7.1 \pm 0.4$ & $0.6 \pm 0.0$ & $7.7 \pm 0.4$ & $2.0 \pm 0.9$ \\
\hline $\mathrm{OP}^{\mathrm{a}}$ & $1.5 \pm 0.1$ & $3.6 \pm 1.1$ & $5.0 \pm 1.0$ & $9.0 \pm 0.6$ & $0.9 \pm 0.1$ & $9.9 \pm 0.6$ & $4.9 \pm 1.2$ \\
\hline
\end{tabular}

Values are mean \pm standard error expressed in $\mathrm{Mg} \mathrm{C} \mathrm{ha}^{-1}$ year ${ }^{-1}$. Values in bold are from this study, values in italic are from the literature review of Hergoualc'h and Verchot (2014)

${ }^{a}$ OP values from this study are the average of results measured in the OP2012 and OP2007

in the forest was a net source of $\mathrm{C}$ emitting at a rate of $2 \mathrm{Mg} \mathrm{C}^{-1}$ year $^{-1}$ (Table 4). This loss rate is very similar to the mean annual net ecosystem exchange of $1.74 \mathrm{Mg} \mathrm{C}^{-1}$ year $^{-1}$ monitored by Hirano et al. (2012) in an intact peat swamp forest of Central Kalimantan. Average peat net $\mathrm{C}$ losses in the plantations are more than twice as large as the losses in the forest. They are within the range of the average net loss rate of $8.2 \pm 2.9 \mathrm{MgC} \mathrm{ha}^{-1}$ year $^{-1}$ computed by Hergoualc'h and Verchot (2014) or the default IPCC emission factor for OP plantations on peat of 11.8 [6.2; 18.1] $\mathrm{Mg} \mathrm{C} \mathrm{ha}^{-1}$ year $^{-1}$, that integrates net decomposition loss $\left(11[5.6 ; 17] \mathrm{Mg} \mathrm{C} \mathrm{ha}^{-1}\right.$ year $\left.^{-1}\right)$ and dissolved organic $\mathrm{C}$ loss $\left(0.8[0.6 ; 1.1] \mathrm{Mg} \mathrm{C}^{-1}\right.$ year $^{-1}$ ) (Drösler et al. 2014).

\section{Conclusion}

Agriculture in peatlands as currently practiced in Southeast Asia by either smallholders or the industry has devastating consequences on the environment (Wijedasa et al. 2017). Peatland-rich countries such as Indonesia need to refine their greenhouse gas emission inventories in this area as a priority. However peat net $\mathrm{CO}_{2}$ emission estimates resulting from forest to oil palm plantation conversion are based on limited data. Peat $\mathrm{C}$ mass balance calculation requires knowledge on rates of $\mathrm{C}$ entering and leaving the peat such as, respectively, litterfall and soil heterotrophic respiration rates. We found a $20 \%$ higher heterotrophic soil respiration in oil palm plantations than in the forest, a result in agreement with, but lower than literature estimates. Separating the components of soil respiration is difficult and simplistic approaches should be regarded cautiously. These include the assumption that total soil respiration measured far from trees is representative of heterotrophic soil respiration. Ideally several methods should be tested simultaneously. Our preliminary $\mathrm{C}$ budget suggests that the peat in the forest was a small source of $\mathrm{C}$ during the observation period. Since climatic variations exert influence on soil respiration, long-term monitoring is required to determine whether the peat continues to be a $\mathrm{C}$ sink or not in this forest. The budget in the plantations underlines $\mathrm{C}$ losses more than twice as high as the losses in the forest, reinforcing current conclusions on the negative impacts on the atmosphere of oil palm cultivation on peat.

\section{Supplementary material}

The database of field measurements of soil respiration and environmental variables is available at http://dx. doi.org/10.17528/CIFOR/DATA.00061.

Acknowledgements This research was conducted under the Sustainable Wetlands Adaptation and Mitigation Program (SWAMP) and was generously supported by the governments of the United States of America (Grant MTO-069018) and Norway (Grant agreement \# QZA-12/0882). It was undertaken as part of the CGIAR research program on Climate Change, Agriculture and Food Security (CCAFS). The authors are grateful to the staff of Tanjung Puting National Park for facilitating the study and providing lodging. We would also like to thank all assistants and villagers for their continuous help in the field. We are extremely thankful to Nisa Novita for contributing to site selection and supporting diligently field work as part of her $\mathrm{Ph} \mathrm{D}$ research activities conducted in the same area. Two referees did their utmost to improve this manuscript; their contribution is much appreciated. 
Open Access This article is distributed under the terms of the Creative Commons Attribution 4.0 International License (http:// creativecommons.org/licenses/by/4.0/), which permits unrestricted use, distribution, and reproduction in any medium, provided you give appropriate credit to the original author(s) and the source, provide a link to the Creative Commons license, and indicate if changes were made.

\section{References}

Aalde H, Gonzalez P, Gytarsky M, Krug T, Kurz WA, Ogle S, Raison J, Schoene D, Ravindranath NH, Elhassan NG, Heath LS, Higuchi N, Kainja S, Matsumoto M, Sanz Sánchez MJ, Somogyi Z, Carle JB, Murthy IK (2006) Volume 4 agriculture, forestry and other land use. Chapter 4: forest land. In: Eggleston HS, Buendia L, Miwa K, Ngara T \& Tanabe K (eds) 2006 IPCC guidelines for national greenhouse gas inventories. Institute for Global Environmental Strategies (IGES), Hayama, Japan

Aini FK, Hergoualc'h K, Smith JU, Verchot L (2015) Nitrous oxide emissions along a gradient of tropical forest disturbance on mineral soils in Sumatra. Agric Ecosyst Environ 214:107-117

Andriesse JP (1988) Nature and management of tropical peat soils. FAO Soils Bull 59:165

Bond-Lamberty B, Thompson A (2010) A global database of soil respiration data. Biogeoscience 7:1915-1926

Carlson KM, Goodman LK, May-Tobin CC (2015) Modeling relationships between water table depth and peat soil carbon loss in Southeast Asian plantations. Environ Res Lett 10:074006

Comeau L-P, Hergoualc'h K, Smith JU, Verchot LV (2013) Conversion of intact peat swamp forest to oil palm plantation: effects on soil $\mathrm{CO}_{2}$ fluxes in Jambi, Sumatra. Working Paper 110. CIFOR, Bogor, Indonesia

Comeau L-P, Hergoualc'h K, Hartill J, Smith J, Verchot LV, Peak D, Salim MA (2016) How do the heterotrophic and the total soil respiration of an oil palm plantation on peat respond to nitrogen fertilizer application? Geoderma 268:41-51

Dariah A, Marwanto S, Agus F (2014) Root- and peat-based $\mathrm{CO}_{2}$ emissions from oil palm plantations. Mitig Adapt Strateg Glob Change 19:831-843

Di Rienzo JA, Casanoves F, Balzarini MG, Gonzalez L, Tablada M, Robledo CW (2014) InfoStat versión 2014. InfoStat Group, Facultad de Ciencias Agropecuarias, Universidad Nacional de Córdoba, Argentina. http:// www.infostat.com.ar

Dommain R, Couwenberg J, Joosten H (2011) Development and carbon sequestration of tropical peat domes in south-east Asia: links to post-glacial sea-level changes and Holocene climate variability. Quatern Sci Rev 30:999-1010

Driessen PM, Rochimah L (1976) The physical properties of lowland peats from Kalimantan (Indonesia). Soil Res Inst Bull 3:12

Drösler M, Verchot LV, Freibauer A, Pan G, Evans CD, Bourbonniere RA, Alm JP, Page S, Agus F, Hergoualc'h K, Couwenberg J, Jauhiainen J, Sabiham S, Wang C,
Srivastava N, Borgeau-Chavez L, Hooijer A, Minkkinen K, French N, Strand T, Sirin A, Mickler R, Tansey K, Larkin N (2014) Chapter 2 drained inland organic soils. In: Hiraishi T, Krug T, Tanabe K, Srivastava N, Jamsranjav B, Fukuda M, Troxler T (eds) 2013 supplement to the 2006 guidelines for national greenhouse gas inventories: Wetlands. IPCC, Geneva

Gaveau DLA, Salim MA, Hergoualc'h K, Locatelli B, Sloan S, Wooster M, Marlier ME, Molidena E, Yaen H, DeFries R, Verchot L, Murdiyarso D, Nasi R, Holmgren P, Sheil D (2014) Major atmospheric emissions from peat fires in Southeast Asia during non-drought years: evidence from the 2013 Sumatran fires. Sci Rep 4:6112

Gumbricht T, Román-Cuesta RM, Verchot LV, Herold M, Wittmann F, Householder E, Herold N, Murdiyarso D (2017) An expert system model for mapping tropical wetlands and peatlands reveals South America as the largest contributor. Glob Change Biol. doi:10.1111/gcb. 13689

Hanson P, Edwards NT, Garten CT, Andrews JA (2000) Separating root and soil microbial contributions to soil respiration: a review of methods and observations. Biogeochemistry 48:115-146

Haron K, Brookes PC, Anderson JM, Zakaria ZZ (1998) Microbial biomass and soil organic matter dynamics in oil palm plantations, West Malaysia. Soil Biol Biochem 30:547-552

Hergoualc'h K, Verchot LV (2011) Stocks and fluxes of carbon associated with land-use change in Southeast Asian tropical peatlands: a review. Glob Biochem Cycles 25:23

Hergoualc'h K, Verchot LV (2014) Greenhouse gas emission factors for land use and land-use change in Southeast Asian peatlands. Mitig Adapt Strateg Glob Change 19:789-807

Hergoualc'h K, Atmadja S, Carmenta R, Martius C, Murdiyarso D, Purnomo H (2017) Managing peatlands in Indonesia: challenges and opportunities for local and global communities. CIFOR Infobrief http://www.cifor.org/library/ 6449/managing-peatlands-in-indonesia-challenges-andopportunities-for-local-and-global-communities/

Hirano T, Jauhiainen J, Inoue T, Takahashi H (2009) Controls on the carbon balance of tropical peatlands. Ecosystems 12:873-887

Hirano T, Segah H, Kusin K, Limin S, Takahashi H, Osaki M (2012) Effects of disturbances on the carbon balance of tropical peat swamp forests. Glob Change Biol 18:3410-3422

Hooijer A, Page S, Canadell JG, Silvius M, Kwadijk J, Wösten $\mathrm{H}$, Jauhiainen $\mathbf{J}$ (2010) Current and future $\mathrm{CO}_{2}$ emissions from drained peatlands in Southeast Asia. Biogeosciences 7:1505-1514

Ishida T, Suzuki S, Nagano T, Osawa K, Yoshino K, Fukumura $\mathrm{K}$, Nuyim $\mathrm{T}$ (2001) $\mathrm{CO}_{2}$ emission rate from a primary peat swamp forest ecosystem in Thailand. Environ Control Biol 39:305-312

Jassal RS, Black TA (2006) Estimating heterotrophic and autotrophic soil respiration using small-area trenched plot technique: theory and practice. Agric For Meteorol 140:193-202

Jauhiainen J, Takahashi H, Heikkinen JEP, Martikainen PJ, Vasander H (2005) Carbon fluxes from a tropical peat swamp forest floor. Glob Change Biol 11:1788-1797 
Jourdan C, Rey H (1997) Architecture and development of the oil-palm (Elaeis guineensis Jacq.) root system. Plant Soil 189:33-48

Könönen M, Jauhiainen J, Laiho R, Spetz P, Kusin K, Limin S, Vasander H (2016) Land use increases the recalcitrance of tropical peat. Wetl Ecol Manag. doi:10.1007/s11273-0169498-7

Kuzyakov Y (2006) Sources of $\mathrm{CO}_{2}$ efflux from soil and review of partitioning methods. Soil Biol Biochem 38:425-448

Linn D, Doran JW (1984) Effect of water-filled pore space on carbon dioxide and nitrous oxide production in tilled and non tilled soils. Soil Sci Soc Am 48:1267-1272

Melling L, Hatano R, Goh KJ (2005) Soil $\mathrm{CO}_{2}$ flux from three ecosystems in tropical peatland of Sarawak, Malaysia. Tellus 57B:1-11

Melling L, Goh KJ, Beauvais C, Hatano R (2007) Carbon flow and budget in a young mature oil palm agroecosystem on deep tropical peat. In: International symposium and workshop on tropical peatland, Yogyakarta, Indonesia, 27-31 August 2007

Melling L, Chaddy A, Goh KJ, Hatano R (2013) Soil CO $\mathrm{CO}_{2}$ fluxes from different ages of oil palm in tropical peatland of Sarawak, Malaysia as influenced by environmental and soil properties. Acta Hortic (ISHS) 982:25-35

Metcalfe DB, Meir P, Aragao LEOC, Mahli Y, da Costa ACL, Braga A, Gonçalves PHL, da Athaydes J, da Almeida SS, Williams M (2007) Factors controlling spatio-temporal variation in carbon dioxide efflux from surface litter, roots, and soil organic matter at four rain forest sites in eastern Amazon. J Geophys Res 112:G04001. doi:10.1029/ 2007JG000443

Miettinen J, Shi C, Liew SC (2016) Land cover distribution in the peatlands of Peninsular Malaysia, Sumatra and Borneo in 2015 with changes since 1990. Global Ecol Conserv 6:67-78

Nelson PN, Banabas M, Scotter DR, Webb MJ (2006) Using soil water depletion to measure spatial distribution of root activity in oil palm (Elaeis guineensis Jacq.) plantations. Plant Soil 286:109-121

Nelson PN, Webb MJ, Banabas M, Nake S, Goodrick I, Gordon J, O'Grady D, Dubos B (2014) Methods to account for treescale variability in soil- and plant-related parameters in oil palm plantations. Plant Soil 374:459-471

Oktarita S, Hergoualc'h K, Anwar S, Verchot LV (2017) Substantial $\mathrm{N}_{2} \mathrm{O}$ emissions from peat decomposition and $\mathrm{N}$ fertilization in an oil palm plantation exacerbated by hotspots. Environ Res Lett 19:1857

Pansu M, Gautheyrou J, Loyer JY (2001) Soil analysis. Sampling, instrumentation, quality control. A.A. Balkema Publishers, Lisse
Pumpanen J, Kolari P, Ilvesniemi H et al (2004) Comparison of different chamber techniques for measuring soil $\mathrm{CO}_{2}$ efflux. Agric For Meteorol 123:159-176

Ruer P (1967) Répartition en surface du système radiculaire du palmier a huile. Oléagineux 22:535-537

Ryan MG, Law BE (2005) Interpreting, measuring, and modeling soil respiration. Biogeochemistry 73:3-27

Sakata R, Shimada S, Arai H, Yoshioka N, Yoshioka R, Aoki H, Inubushi K (2015) Effect of soil types and nitrogen fertilizer on nitrous oxide and carbon dioxide emissions in oil palm plantations. Soil Sci Plant Nutr 61:48-60

Sayer EJ, Tanner EVJ (2010) A new approach to trenching experiments for measuring root-rhizosphere respiration in a lowland tropical forest. Soil Biol Biochem 42:347-352

Subke J-A, Inglima I, Cotrufo MF (2006) Trends and methodological impacts in soil $\mathrm{CO}_{2}$ efflux partitioning: A metaanalytical review. Glob Change Biol 12:921-943

Swails E, Hertanti D, Hergoualc'h K, Verchot LV, Lawrence D (2017) Seasonal and interannual variation in total soil respiration from an Indonesian peatland. Manuscript in preparation

Thomas GW (1996) Soil pH and soil acidity. In: Bigham JM (ed) Methods of soil analysis: Part 3-chemical methods. Soil Science Society of America Book Series No. 5. Soil Science Society of America and American Society of Agronomy, Madison, pp 475-490

Wan S, Hui D, Luo Y (2001) Fire effects on nitrogen pools and dynamics in terrestrial ecosystems: a meta-analysis. Ecol Appl 11:1349-1365

Wang X, Zhu B, Wang Y, Zheng X (2008) Field measures of the contribution of root respiration to soil respiration in an alder and cypress mixed plantation by two methods: trenching method and root biomass regression method. Eur J For Res 127:285-291

Warren MW, Kauffman JB, Murdiyarso D, Anshari G, Hergoualc'h K, Kurnianto S, Purbopuspito J, Gusmayanti E, Afifudin M, Rahajoe J, Alhamd L, Limin S, Iswandi A (2012) A cost-efficient method to assess carbon stocks in tropical peat soil. Biogeosci Dis 9:7049-7071

Warren M, Hergoualc'h K, Kaufman JB, Murdiyarso D, Kolka R (2017) An appraisal of Indonesia's immense peat carbon stock using national peatland maps: uncertainties and potential losses from conversion. Carbon Balance Manag $12: 12$

Wijedasa LS et al (2017) Denial of long-term issues with agriculture on tropical peatlands will have devastating consequences. Change Biol Glob. doi:10.1111/gcb.13516

Yule CM, Gomez LN (2009) Leaf litter decomposition in a tropical peat swamp forest in Peninsular Malaysia. Wetl Ecol Manag 17:231-241 